\section{Nastamonu Eğitim Dergisi Kastamonu Education Journal}

Ocak 2019 Cilt:27 Sayı:2

kefdergi.kastamonu.edu.tr
Başvuru Tarihi/Received: 19.01.2018

Kabul Tarihi/Accepted: 21.06.2018 DOI: $10.24106 /$ kefdergi.2577

\title{
Öğretmen Adaylarının Yansıtıcı Düşünme Becerileri ve Bu Becerilerin Gelişimini Destekleyen Faktörler'
}

\section{Reflective Thinking Skills of Pre-Service Teachers And Factors That Enhance The Reflective Thinking}

\section{Öz}

\author{
Gülnur ÖZBEK², Erdoğan KÖSE ${ }^{3}$
}

Araştırmanın amacı sınıf öğretmenliği lisans programının 7. döneminde okutulan öğretmenlik uygulaması-ı dersini almakta olan öğretmen adaylarının öğretim sürecinde yansıtıcı düşünme becerilerini nasıl kullandıklarını, ne gibi durumlar üzerine yansıtma yapttklarını ortaya koymak ve bu süreçte yansıtıcı düşünme becerilerinin gelişimini destekleyen faktörleri belirlemektir. Araştırma nitel araştırma yöntemlerinden eylem araştırmasına göre desenlenmiştir. Çalışma grubunu oluşturan altı öğretmen adayının 10 haftalık öğretmenlik uygulaması süreci incelenmiştir. Haftalık yansıtıcı günlükler, görüşmeler, uygulama derslerinin video kayıtları, uygulama ortası ve sonu algı anketleri ve akran önerileri bu çalışmanın veri toplama kaynaklarıdır. Verilerin analizinde içerik analizi ve betimsel analiz kullanılmıştır. Öğretmen adaylarının hedef, içerik, eğitim durumları ve sınama durumları olarak 4 kategori altında 10 farklı temaya yönelik yansıtma kararları aldıkları ve en çok eğitim durumları üzerine yansıtma yaptıkları sonucuna ulaşılmıştr. Yansıttcı düşünme becerilerinin gelişimini destekleyen 10 faktörün; öğretim uygulamalarının video kaydı, yansıtıcı günlükler, akran işbirliği, öğretim deneyimi, uygulama öğretmeniyle işbirliği, ders planı hazırlama, öğretim uygulaması sonrası yapılan görüşmeler, öğretim uygulamalarında uzun süreli iletişim, güven verici ve destekleyici düşünme ortamı, pedagojik alan bilgisi olduğu sonucuna ulaşılmıştır.

Anahtar Kelimeler: Yansıtıcı düşünme, öğretmen eğitimi, öğretmenlik uygulaması, eğitim programı

\section{Abstract}

The aim of this study is to analyze the reflective thinking skills of pre-service teachers and to identify factors that enhance the reflective thinking skills during the practicum settings of pre-service teachers at department of classroom teaching. Study was conducted in the form of action research in qualitative research paradigm. Ten week practicum proces of 6 pre-service teachers were constructed. Data collection consisted of weekly guided diary entries, interviews, camera-recorded practicum settings, mid and end of course perception questionnaires and peer feedbacks. The study showed that 10 reflective themes were documented under four categories(objectives, content, teaching-learning process and evaluation) and pre-service teachers focused primarily on the instructional processes. Content and descriptive analysis method was employed. The study revealed that following 10 factors was important in development of pre-service teachers' reflective thinking skills; video-recorded practicum settings, reflective journals, peer cooperation, teaching experience, cooperation with school advisor, preparing lesson plans, Interviews made after practicum settings, long-term communication in practicum settings, free thinking environment and supports, pedagogical knowledge.

Keywrods: Reflective thinking, teacher education, practicum settings, curriculum

1. Birinci yazarın, Akdeniz Üniversitesi Bilimsel Araştırma Projeleri Birimi tarafindan desteklenen yüksek lisans tezinden üretilmiştir. Araştımanın bir bölümü 4. Uluslararası Eğitim Programları ve Öğretim Kongresinde 27-30 Ekim 2016 tarihinde Antalya'da sözlü bildiri olarak sunulmuştur.

2. Antalya Bilim ve Sanat Merkezi, Antalya, Türkiye; https://orcid.org/0000-0001-9395-5022

3. Akdeniz Üniversitesi, Antalya, Türkiye; https://orcid.org/0000-0003-0426-0267

Atıf / Citation: Özbek, G., \& Köse, E.(2019). Öğretmen adaylarının yansıtıcı düşünme becerileri ve bu becerilerin gelişimini destekleyen faktörler. Kastamonu Education Journal, 27(2), 537-554. doi:10.24106/kefdergi.2577 


\section{Extended Summary}

Reflective thinking skills, a preliminary step for gaining, developing and shaping professional competence is a frequently used concept in teacher education in context of pre-service teachers configuring their knowledge about their reflective applications and gaining more learning experience. Seen as the key figure of many teacher education curriculums, reflective thinking is the thinking process oriented to reveal positive and negative circumstances and solve problems regarding the pre-service teachers' ways of teaching, learning and their competency. Factors that enhance the reflective thinking skills of pre-service teachers contribute to the training of pre-service teachers and it helps develop teaching and learning environments that are more effective.

Purpose: The aim of this study is to analyze the reflective thinking skills of pre-service teachers and to identify factors that enhance the reflective thinking skills during the practicum settings of pre-service teachers.

Method: The research has been designed in compliance with one of the qualitative methods action research. Practicum settings of six senior year students who form the research group of the work have been studied systematically and in detail. The research has been conducted as a part of Teacher Practicum Settings-I lesson that has been given in senior year's first term to pre-service teachers. 10week practicum processes of 6 pre-service teachers were detailed constructed. Data collection consisted of weekly guided reflective diary entries, tape-recorded reflective interactions and interviews, camera-recorded practicum lessons/settings, mid and end of course perception questionnaires and peer feedbacks. Mid and end of course perception questionnaires have been used to designate pre-service teachers' perceptions about the practicum settings. Perceptions of the pre-service teachers have been supported with data recorded throughout the practicum settings to assert factors that enhance the reflective thinking skills. The data were collected from journal of pre-service teachers who kept journals on a regular base and interviews in groups of three pre-service teachers which involved their personal thoughts and interpretations of their practice. Content and descriptive analysis method was employed in the data.

The research has been validated using the methods of expert views, participant confirmation and detailed depiction while the reliability of the research was ensured using confirmation and stability analysis. There were multiple methods of data collection used to ensure internal validity, resulting in its diversification. The data was encoded by two independent coders and a match of 0.83 was recorded.

Results and Discussion: The study showed that student teachers reflect on teaching practices with regard to four basic element of curriculum development. It was indicated that the pre-service teachers focused primarily on the instructional processes.

The study revealed that following factors was important in development of pre-service teachers' reflective thinking skills in this process: video-recorded practicum lessons/settings, weekly guided reflective journal entries, peer cooperation, teaching experience and direct contacts with students, cooperation with an school advisor, preparing lesson plans, Interviews made after practicum settings, long-term communication in practicum settings, free thinking environment that reassures and supports, pedagogical knowledge. It was concluded that during weekly interviews held with pre-service teachers after practicum settings, pre-service teachers have been exchanging ideas to evaluate their teaching processes, making decisions regarding the designing of the next lessons, find and correct their shortcomings, compensate their mistakes and criticize themselves objectively. It was determined that entering weekly guided reflective journals regularly during the process is effective in the development of the reflective thinking skills. It was found out that the skills and knowledge of the pre-service teachers about teaching have developed, they have gained self-awareness and got a chance to question and evaluate everything they've done during the lesson. Pre-service teachers have reported that, thanks to videos, they were able to see aspects of themselves they haven't noticed during the practicum settings clearer, they were able to be more comfortable in the class, were given opportunity to develop themselves in for future lessons and they would have got a chance to see how they developed their own vocational skills. Pre-service teachers have reported that long-term communication in practicum settings had positive contribution in formation of their professional identities. It was also revealed that gaining teaching experience in an authentic environment has positive effects for pre-service teachers' reflective thinking. According to research results, teachers have emphasized that the practicum settings taking place in an authentic classroom environment is important to the development their reflective thinking. They have added that they could incorporate their experiences into theoretical knowledge, develop their teaching skills, make efforts and all of this is important for their vocational development. As a continuation of the practicum settings carried out by pre-service teachers, it was recorded that preparing lesson plans that include their reflections about the planning of the next lesson has contributed to reflective thinking. Pre-service teachers have expressed opinions that these plans have contributed to the development of their teaching skills. It was also determined that pre-service teachers are more effective in teaching when they use their pedagogical knowledge to solve problems they face in practicum settings and perform reflection in that context. It was highlighted supportive and free thinking environment is a requirement for reflective thinking. 


\section{Giriş}

Mesleki yeterliliklerin kazanılmasında ve geliştirilmesinde bir ön basamak olan yansıtıcı düşünme becerisi, öğretmen adaylarının öğretim uygulamalarıyla ilgili bilgilerinin yapılandırılmasını ve öğrenme deneyimlerinin artmasını sağlaması bağlamında öğretmen eğitiminde oldukça sık gözlemlenen ve incelenen bir kavramdır (Clarke, 1995; Fazaklı ve Kuru-Gönen, 2017; Gün, 2011; Jay ve Johnson, 2002; Köksal ve Demirel, 2008; Schön, 1983). Öğretmen eğitiminde yansıtıı düşünme, uygulama ile teorinin her birinin bir diğerini güçlendirmesini sağlayıcı etkiye sahiptir (Adler, 1991). Bu bağlamda birçok öğretmen eğitimi programının anahtar kavramı olarak görülen yansıtıcı düşünme kavramı farklı yaklaşımlarla açıklanmıştır (Brockbank ve McGill, 2000; Ekiz, 2006; Erginel, 2006; Ferraro, 2000). Dewey (1933), yansıtıcı düşünmeyi amaçlanan sonuçlara ulaşmayı destekleyen etkin, sürekli ve dikkatli bir biçimde düşünme olarak tanımlamaktadır. Yansıtıcı düşünmenin rahatsızlık algısı üzerine kurulan bir sorgulama döngüsü olduğunu ifade eden Schön (1983), yansıtmanın iki temel yapısının "eylem sırasında yansıtma" ve "eylemden sonra eylem hakkında yansıtma" olduğunu belirtmiştir. Bu bağlamda yansıtma, öğrenme-öğretme sürecine ilişkin olumlu ve olumsuz durumları ortaya çıkarmaya ve sorunları çözmeye yönelik düşünme sürecidir (Bigge ve Shermis, 1999; Kember ve diğerleri, 1999; Ünver, 2003). Bu düşünme süreci, iki öğretim deneyimi arasında tekrar eden döngüsel bir yapıdadır.

Öğretmen eğitiminde yer alan Öğretmenlik Uygulaması derslerinin hedefi, öğretmen adaylarının uygulama deneyimi kazanmalarını ve kendi öğretim süreçleri üzerinde düşünmelerini sağlayarak onların mesleki uzmanlıklarının gelişmesine katkı sağlamaktı (Akbari, 2007; YÖK, 1999). Bu dersler kapsamında yansıtıcı düşünmenin kullanılması ve geliştirilmesi öğretmen adaylarının öğretme deneyimlerinin verimliliğini artırmalarında (Dolapçıoğlu, 2007; Koç ve Yıldız, 2012) ve mesleki uzmanlıklarını geliştirmelerinde etkilidir (Fazaklı ve Kuru-Gönen, 2017; Korumaz ve Karakaş, 2014; Köksal ve Demirel, 2008; Oruç, 2000). Uygulamaların daha verimli olması için öğretmen adayının bir önceki ders performansını gözden geçirip gelecekteki ders performansı konusunda önlem almasını sağlamak gereklidir. Ders performansını gözden geçirme süreci içinde tüm öğretim uygulamalarında etkili olan değişkenler sorgulanmaktadır (Schön, 1987). Öğretime ilişkin etkili olan ve olmayan tüm değişkenlerin sorgulanmasını kapsayan yansıtıcı düşünme, öğretmen adaylarını öğretim sürecinde çıkabilecek sorunları belirleyip bu sorunların üstesinden gelmek için çözüm üretmeye hazırlamaktadır (Shoffner, 2008). Bunların yanı sıra öğretmen adaylarının öğrencileri daha iyi tanımasına, dersi hem kendi hem de öğrencinin yeteneklerine göre yönlendirmesine, kullanılan araçlar sayesinde farklı fikir ve tecrübelere açık, aktif bir sınıf ortamı oluşturmasına katkı sağlamaktadır. Kendi fikirlerini sorgulayabilme ve etkili biçimde aktarabilme, öğrenci fikirlerini anlayabilme gibi becerilerin yansıtıcı düşünen öğretmen özelliklerinden olduğu düşünüldüğünde, öğretmen eğitiminde yansıttcı düşünme becerilerinin geliştirilmesi oldukça önemlidir (Rodgers, 2002).

Öğretim uygulamalarında kullanılan yansıtıcı bileşenlerden bazıları; yansıtma günlükleri, derslerin video kayıtları, yüksek sesle düşünme, grup tartş̧maları ve yansıtıı diyaloglardır. Öğretmen yetiştirmede bu bileşenlere yer verilmesi eğitimin niteliğinin arttıılmasına ve yansıtıcı düşünen öğretmen adaylarının yetiştirilmesine katkı sağlamaktadır (Bağcıoğlu, 1999; Bigge ve Shermis, 1999; Clarke, 1995; Erginel, 2006; Kızllkaya ve Askar, 2009; Köksal ve Demirel, 2008; Ünver, 2003; Wubbels ve Korthagen, 1990). Yansıtmayı artıran bileşenler öğretmen adayı, uygulama öğretmeni ve üniversite ile ilişkili olarak gruplandırılabilmektedir (Clarke, 1995). Bileşenlerden biri olan akranlarla paylaşım, tartışma ve ortaklaşa yapılan yansıtmalar mesleki gelişimi ve yansıtıcı düşünmeyi arttırmaktadır (Bağcıoğlu, 1999; Brookfield, 1995; Fazaklı ve Kuru-Gönen, 2017; Stoddard, 2002). Yansıtıcı günlük yazımı öğretim uygulamalarına ilişkin çıkarımlarda bulunmada, bireysel farkındalığı geliştirmede ve yansıtıcı düşünmeyi arttırmada faydalı olmaktadır (Fazaklı ve Kuru-Gönen, 2017; Roskos, 2001; Stoddard, 2002). Öğretmen adaylarının kendi öğretim uygulamalarının video kayıtlarını izlemeleri (Eröz-Tuğa, 2013; Göde, 1999), öğretim süreçleri sırasında koşulları değerlendirmeleri ve uygulamaları tekrar gözden geçirmeleri öğretim kalitesini ve yansıtıcı düşünmeyi arttırmaktadır (Erginel, 2006; Köksal ve Demirel, 2008; Pollard, 2002).

Yansıtıcı düşünme becerisinin katkısı ve mesleki uzmanlık geliştirme açısından önemi çeşitli araştırmalarla gösterilmesine rağmen öğretmen adaylarına, öğretim deneyimlerini yeterince yansıtma olanakları verilememektedir (Dewey, 1933; Dolapçığlu, 2007; Erginel, 2006; Fazaklı ve Kuru-Gönen, 2017; Korumaz ve Karakaş, 2014). Öğretmen adaylarının yansıtıcı düşünme becerisini nasıl kullandıklarının ve ne gibi durumlar üzerine yansıtma yaptıklarının ortaya konulması daha etkili öğrenme ve öğretme ortamlarının geliştirilmesi açısından önemlidir (Bartlett ve Burton, 2006; Clarke, 1995; Dewey, 1933; Pollard, 2002; Schön, 1983). Ayrıca öğretmen adaylarının öğretim süreçleri sırasında neyi niçin öğreteceklerini sorgulayarak yeterli ve yetersiz oldukları kısımlar üzerine düşünmelerini sağlayacak yansıtıcı düşünme becerilerinin araştırılması mesleki gelişim açısından önemlidir (Dewey, 1933; Schön, 1983).

\section{ilgili Araştırmalar}

Öğretmen eğitiminde yansıtıcı düşünmeyle ilgili Schön'ün yaklaşımında yansıtıcı düşünme döngüsel bir süreç olup dört 
bileşeni vardır. Bu bileşenlerden ilki öğretim uygulamalarına ilişkin farkındalık oluşturan ve yansıtıcı düşünmeyi başlatan rahatsızlık algılarıdır. İkincisi rahatsızlık durumunu gidermek ve iyileştirmek için alınan düzenleme kararları, üçüncüsü mevcut uygulamaları değerlendirerek alınan yeniden düzenleme kararları ve dördüncüsü ileriki uygulamalar için alınan plan ve tasarım kararlarıdır (Schön, 1983; 1987). Öğretmen eğitimiyle ilgili araştırmalarda Schön'ün yaklaşımı temel alınarak yansıtıcı düşünme bu bileşenler altında alınan kararlara odaklanılarak analiz edilebilmektedir (Clarke, 1995). Erginel (2006) araştırmasında öğretmen adaylarının uygulama sürecinde öğretim yöntemleri ve öğrenci güdülenmesi gibi konulara yoğunlaşarak yansıtıcı düşünmede gelişme kaydettiklerini belirtmektedir. Brookfield (1995) ve Stoddard (2002) araştırmalarında öğretmen eğitiminde yansıtıcı düşünme becerilerinin akranlarla paylaşım sağlanarak desteklenebileceğini Fazaklı ve Kuru-Gönen (2017), Halim, Buang ve Meerah (2010) ve Tang (2000) ise araştırmalarında öğretmen adaylarının kendi eğitim uygulamalarına ilişkin değerlendirme yapmalarında günlük tutmanın olumlu etkisini ortaya koymaktadırlar. Fatemipour (2013) araştırmasında günlüğün yansıtmada en etkili araç olduğunu belirtmektedir. Eröz-Tuğa (2013), Lakshmi (2014) ve Göde (1999) araştırmalarında öğrenme ortamlarında video kayıtları kullanımının birçok boyut hakkında farkındalık geliştirerek öğretimdeki yansıtma sürecine olumlu yönde katkı sağladığını ortaya koymaktadırlar.

\section{Araştırmanın Amacı}

Araştırmanın amacı sınıf öğretmenliği lisans programının 7. döneminde okutulan öğretmenlik uygulaması-ı dersini almakta olan öğretmen adaylarının öğretim sürecinde yansıtıcı düşünme becerilerini nasıl kullandıklarını, ne gibi durumlar üzerine yansıtma yaptıklarını ortaya koymak ve bu süreçte yansıtıcı düşünme becerilerinin gelişimini destekleyen faktörleri belirlemektir. Bu amaç doğrultusunda aşağıdaki sorulara yanıt aranmaktadır.

- Öğretmen adayları öğretim sürecinde ne gibi durumlar üzerine yansıtma yapmaktadırlar?

- Öğretmen adayları öğretim sürecinde yansıtıcı düşünme becerilerini nasıl kullanmaktadırlar?

- Öğretmen adaylarının yansıtıcı düşünme becerilerinin gelişimini destekleyen faktörler nelerdir?

\section{Yöntem}

\section{Araştırma Modeli}

Araştırma nitel araştırma yöntemlerinden eylem araştırmasına göre desenlenmiştir. Eylem araştırmasında, derinlemesine bilgi elde etmek için sistematik olarak veri toplamaya odaklanılır ve mesleki gelişim sağlanır (Johnson, 2010).

\section{Çalışma Grubu ve Bağlam}

Araştırmanın çalışma grubunu, sınıf öğretmenliği lisans programına devam eden ve diğer derslerini başarıyla tamamlayarak 7. yarıyılda okutulan öğretmenlik uygulaması-ı dersini almakta olan 6 (4 kadın, 2 erkek) öğretmen adayı oluşturmaktadır. Katılımcılardan beşi bu dersi yedinci dönemde almakta iken bir katılımcı dönem uzattı̆ı için dokuzuncu dönemde almıştır. Not ortalaması sınıf ortalamasının oldukça üzerinde olan iki katılımcı dışındakilerin ortalaması sınıf ortalamasındadır. Farklı iki sınıfta öğretim uygulaması yapacak olan katılımcılar üçer kişilik gruplara rastgele ayrılmışlardır. Gruplara rehberlik edecek iki uygulama öğretmeni de gruplara rastgele atanmıştır. Süreç boyunca bir grupta yer alan üç katılımcı aynı uygulama öğretmeninden destek almıştır.

Araştırma, sınıf öğretmenliği programı son sınıflarında güz döneminde okutulan "Öğretmenlik Uygulaması-I" dersi bağlamında gerçekleştirilmiştir. Dersin hedefi öğretmen adaylarının teorik bilgilerini uygulamalarını sağlamak ve mesleki uzmanlıklarının gelişmesini desteklemektir (YÖK, 1998). Bu ders bağlamında öğretmen adayları sınıf kontrolü ve öğretimde sorulardan yaralanma gibi dönem boyunca tamamlamaları gereken konuları içeren öğrenci kılavuzunu kullanmaktadırlar. Öğretmen adaylarından her hafta öğretim uygulamasından önce plan hazırlamaları beklenmektedir. Araşttrmada "Öğretmenlik Uygulaması-I" dersi bağlamında klavuzda belirtilen içeriklere bağlı kalınmıştır (Ek, 1).

\section{Veri Toplama Araçları}

Öğretmen adaylarının haftalık yansıtıcı düşünme günlükleri, görüşme formu, öğretmen adaylarının haftalık akran geribildirimleri formu, uygulama ortası ve sonu algı anketleri araştırmacılar tarafindan hazırlanmıştır. Bu veri toplama araçlarında yer verilen rehber ifadeler ve sorular için alan yazında yer alan çalışmalardan (Brookfield 1995; Erginel 2006; Opp-Beckman ve Klinghammer, 2006) yararlanılmıştır. Taslak formlar oluşturulmuştur. Oluşturulan taslak formlar hakkında uzman görüşü (ölçme ve değerlendirme, program geliştirme, yazım ve dil bilgisi) alınmış ve gerekli düzeltmeler yapılarak son haline ulaşılmıştır.

Öğretmen adaylarının haftalık yansıtıcı düşünme günlükleri. Araştırmacılar tarafindan öğretmen adaylarından öğretim uygulamaları üzerinde düşünmeleri ve deneyimlerini yansıtmaları için günlükler hazırlanmıştır. Günlükler, öğret- 
men adaylarına kendi deneyimlerini yansıtmalarında yardımcı olması amacıyla dört kategori (dersin hedefleri, etkinlikler ve materyaller, sınıf yönetimi, dersin genel çerçevesi) ve bu kategoriler altında 24 rehber ifade içermektedir (Ek, 2).

Görüşme formu. Kullanılan yarı yapılandırımış görüşme formu 11 açık uçlu sorudan oluşmaktadır. Görüşme formundaki sorularda derslerin genel değerlendirilmesi, hedefleri, öğretim koşulları, öğretim strateji, yöntem ve teknikleri, planlanmayan/istenmeyen öğrenme ürünleri/olaylar, öğrencilerin davranışları ve çözüm önerileri üzerinde durulmuştur (Ek, 3).

Öğretmen adaylarının haftalık akran geribildirimleri formu. Öğretmen adayları, çalışma kapsamında birbirlerinin öğretim uygulamalarını gözlemlemiş ve bu gözlemleri doğrultusunda akranlarına önerilerde bulunmuşlardır. Aynı sınıfta öğretim uygulaması yapan adaylar birbirlerini gözlemleyerek form üzerine notlar almışlardır. Öğretmen adaylarının 10 haftalık süreç boyunca her hafta yaptıkları öğretim uygulaması aynı grupta olan diğer iki akranı tarafindan gözlemlenmiştir. Bu form öğretmen adaylarının 10 hafta boyunca birbirlerinin öğretim uygulamalarına ilişkin geribildirimlerini içeren bir veri kaynağıdır. Formda açık uçlu bir soru, bu soruya paralel 4 rehber ifade ve öğretmen adaylarının serbest notlar alabilecekleri bölüm yer almaktadır (Ek, 4).

Uygulama derslerinin video kayıtları. Öğretmen adaylarının 10 haftalık öğretim uygulamalarının video ile kayıt altına alınmıştır. Derslerden sonra, bu kayıtların bir kopyası öğretmen adayları ile paylaşılmıştır. Bu videolar öğretmen adaylarının bireysel olarak kendilerini izleyerek kritik edip bir sonraki öğretim uygulaması için yansıtmalar yapmaları ve bu yansıtmalarını o haftaki yansıtıcı günlüklerine not etmeleri için kullanılmıştır. Ayrıca diğer veri kaynakları ile birlikte verinin çeşitlendirilmesi amacına hizmet etmiştir. Öğretmen adaylarının öğretim uygulamaları sırasında farkında olmadıkları yönlerini görebilmeleri ve hatırlamaları açısından araştırmaya katkı sağlamıştı.

Algı anketleri. Öğretmen adaylarının araştırma sürecine ve yansıttcı bileşenlere ilişkin görüşlerini almak ve sürecin kendilerine olan katkılarını izlemek amacıyla uygulama ortası ve uygulama sonu olmak üzere iki algı anketi uygulanmıştır. Öğretmen adaylarının yansıtııı görüşmeler, akran önerileri ve kendi rolleri gibi geribildirimlerini ve önerilerini öğrenmeyi amaçlayan uygulama ortası anketinde sekiz (Ek, 5), uygulama sonu anketinde dokuz soruya yer verilmiştir (Ek, 6).

\section{Verilerin Toplanması}

İlk iki hafta, katılımcılar ile toplantılar planlanmış ve sürece yönelik açıklamalarda bulunulmuştur. Sonraki 10 hafta boyunca 6 öğretmen adayının her biri her hafta bir ders saati süresince öğretim uygulaması yapmıştır. Bu süreçte öğretim uygulamalarına ilişkin katılımcıların tuttukları günlük notları düzenli olarak toplanmış, sınıf içi öğretim uygulamalarının video kayıtları tutulmuş, akran önerileri formları toplanmış ve uygulama dersi deneyimlerine yönelik yansıtmaları görüşmelerle kayıt altına alınmıştır (Ek, 1). Öğretmen adaylarının her biri öğretim uygulamaları sırasında ve sonrasında aldıkları yansıtma kararlarını bir sonraki hafta derste uygulamışlardır. Sadece öğretmen adaylarının kendi uygulamaları üzerinde yaptıkları yansıtmaları değil aynı zamanda akranlarının uygulamaları üzerine yaptıkları yansıtmaları da belirlenmek istendiği için görüşmeler grup görüşmesi olarak gerçekleştirilmiştir. Aynı sınıfta, farklı derslerde uygulama yapan üç öğretmen adayı ile aynı anda görüşme yapıımıştır. Sürecin bir parçası olarak aynı sınıfta öğretim uygulaması yapan üç öğretmen adayının her biri diğer iki arkadaşı tarafindan gözlemlenmiştir. Uygulama ortası ve uygulama sonu algı anketi 5. ve 10. haftada uygulanmıştır. Araştırmacı sürecin kontrolü için 10 hafta boyunca zamanını katılımcılar arasında geçirmiş ancak katılımcıların serbestçe yansıtma yapmalarını olumsuz etkileyecek şekilde herhangi bir etki yapmamıştı.

\section{Verilerin Analizi}

Verilerin analizinde betimsel analiz ve içerik analizi kullanılmıştır. Veriler öğretmen adaylarının ne gibi durumlar üzerine yansıtıcı düşünme becerilerini nasıl kullandıkları (1. ve 2. araştırma sorusu) ve bu becerilerin gelişimini destekleyen faktörler (3. araştırma sorusu) olmak üzere iki boyutta analiz edilmiştir. Araştırmanın 1. ve 2. sorusuyla ilgili analizlerde kullanılan veri kaynakları görüşme, günlük ve akran geribildirimleridir. Araştırmanın 3. sorusuyla ilgili analizlerde kullanılan veri kaynakları algı anketleri olup katılımcıların algı anketlerindeki yansıtıı bileşenlerle ilgili ifadeleri 10 haftalık süreçte gerçekleştirme durumları diğer veri kaynakları kullanılarak kontrol edilmiştir. Örneğin algı anketinde günlük ile ilgili bir ifade varsa katılımcının günlük kayıtları kontrol edilerek doğrulanmıştır. Birinci araştırma sorusunun analiz sürecinde alan yazında benzer araştırmalarda ulaşılan temalardan (Clarke, 1995; Erginel, 2006; Köksal ve Demirel, 2008) yararlanarak araştırmada elde edilen verilerden ortaya çıkan yeni temalara (yansıtma kararları) ulaşılmıştır. Ulaşılan temaları açıklayan verilerin 10 haftalık süreç içerisinde hangi döngülerde (iki öğretim uygulaması arası bir haftalık süreç) hangi yansıtıcı bileşenden elde edildiği analiz edilmiştir. Her döngüde üç farklı yansıtıcı bileşen (X: yansıtıcı günlük, Y: görüşme formu, Z: akran önerileri formu) ile 5. ve 10. döngüde yer alan iki farklı yansıtıcı bileşen (T: uygulama ortası algı anketi, V: uygulama sonu algı anketi) olmak üzere toplam alt yansıtıı bileşen çalışma sürecinde katılımcılar 
tarafindan gerçekleştirilmiştir. İkinci araştırma sorusunu analiz etmek ve yansıtma kararlarını 10 haftalık süreçte nasıl gerçekleştiğini belirlemek için iki boyutlu tablolar oluşturulmuştur. Bu tablolarda yatay boyutta her katılımcının nasıl yansıtma yaptığının ve yansıttcı düşünme döngüsünün analizinde Schön'ün (1987) yansıtıcı düşünme modelinin aşamaları (farkındalık durumu, düzenleme kararları, yeniden düzenleme kararları, sonraki uygulama planı) kullanılmıştr. Örnek kodlama Tablo 1'de verilmiştir. Uzman görüşü, kathlımcı teyidi ve ayrıntılı betimleme yöntemleriyle araştırmanın geçerliği, teyit ve tutarlık incelemesiyle de araştırmanın güvenirliği sağlanmıştı. Araştırmada iç geçerliliği artırmak veri toplamada çeşitlilik sağlanmıştır. Veriler iki farklı kodlayıcı tarafindan bağımsız olarak kodlanarak 0.83 uyum elde edilmiştir (Landis ve Koch, 1977) ve uyumsuzluklara yansıtıcı düşünme döngüsünde alınan kararlarda karşılaşılmıştır.

\section{Tablo 1. Yansıtıcı düşünme döngüsü için örnek kodlama}

\begin{tabular}{|c|c|c|}
\hline Yansıtma Teması & Açıklama & Örnek \\
\hline farkındalık durumu & $\begin{array}{l}\text { öğretim uygulamalarına ilişkin rahatsız- } \\
\text { lık algısı oluşturan farkındalık durumları }\end{array}$ & $\begin{array}{r}\text { “...5 dakika sonra gürültü başladı. } \\
\text { rakmak zorunda kald }\end{array}$ \\
\hline düzenleme kararları & rahatsızlığı gidermek için alınan kararlar & $\begin{array}{c}\text { “...üstesinden gelmek için etkinlik yönergelerini daha } \\
\text { net ifade etmeliydim.” }\end{array}$ \\
\hline yenider & $\begin{array}{l}\text { mevcut uygulamaları değerlendirerek } \\
\text { yeniden düzenlemek için alınan kararlar }\end{array}$ & $\begin{array}{c}\text { "planlama, düzeltme ve kontrollere daha fazla özen } \\
\text { göstermeliyim." }\end{array}$ \\
\hline sonraki uygulam & $\begin{array}{c}\text { ileriki uygulamalar için alınan plan ve } \\
\text { tasarım kararları }\end{array}$ & $\begin{array}{l}\text { "...sonraki derslerimde sınıf kurallarını ve etkinlik yö- } \\
\text { nergelerini net olarak derse girişte ifade etmeliyim." }\end{array}$ \\
\hline
\end{tabular}

\section{Bulgular ve Yorumlar}

Görüşme, günlük ve akran geribildirimlerinden elde edilen verilerin analizinden öğretmen adaylarının 10 haftalık süreçte öğretim uygulamalarına ilişkin yansıtma kararlarıı programın dört temel öğesi olan hedef, içerik, eğitim durumları ve sınama durumları olarak kategoriler altında aldıkları bulunmuştur. Tablo 2'de ulaşılan 10 farklı yansıtııı düşünme kararı veri analizi bölümünde örnek kodlamada açıklanan farkındalık durumları ile başlayan ve ilerleyen haftalarda o farkındalık durumu üzerine yansıtmaların devam ettiği temalardır. Bir farkındalık durumunun başladığı hafta ile o farkındalık durumu üzerine yansıtmaların yapılmadığı hafta aralığında yapılan tüm yansıtmalar bütün olarak düşünüldüğünden bir tema olarak sayılmıştr.

\section{Tablo 2. Öğretmen Adaylarının Yansıtıcı Düşünme Kararları}

\begin{tabular}{|c|c|c|c|c|c|c|c|c|}
\hline \multirow[t]{2}{*}{ Program Öğeleri } & \multirow[t]{2}{*}{ Katılımcıların Yansıtıcı Düşünme Kararları } & \multicolumn{6}{|c|}{ Katilımcılar } & \multirow[t]{2}{*}{ Toplam } \\
\hline & & A & $\mathrm{B}$ & $\mathrm{C}$ & $\mathrm{D}$ & $\mathrm{E}$ & $\mathrm{F}$ & \\
\hline Hedef & plan ve tasarım kararları & 1 & & & & & & 1 \\
\hline İçerik & içerik seçme ve düzenleme kararları & 1 & & & & & & 1 \\
\hline \multirow[t]{6}{*}{ Eğitim durumları } & $\begin{array}{c}\text { strateji, yöntem, teknik, etkinlik ve materyal seçme } \\
\text { ve uygulama kararları }\end{array}$ & 2 & 1 & & & & 1 & 3 \\
\hline & $\begin{array}{c}\text { planlanmayan/beklenmeyen olaylar/öğrenme ürün- } \\
\text { lerinin üstesinden gelme kararları }\end{array}$ & & & 1 & & 1 & & 2 \\
\hline & geribildirim verme ve hataları düzeltme kararları & 1 & 1 & & & & & 2 \\
\hline & dersin yönetimi ve sınıf kontrolü kararları & & & 1 & & & & 2 \\
\hline & öğrenci motivasyonu ve sınıf atmosferi kararları & & & & 1 & & & 1 \\
\hline & söz hakkı verme ve öğrenci katılımı sağlama kararları & 1 & & & & & & 1 \\
\hline \multirow[t]{2}{*}{ Sınama durumları } & hedeflere ulaşma kararları & & 1 & & & & & 1 \\
\hline & sınama durumlarına zaman ayırma kararları & & & & 1 & & & 1 \\
\hline Toplam & & 6 & 3 & 2 & 2 & 1 & 1 & \\
\hline
\end{tabular}

Tablo 2'de, A, B, C, D, E, F kodlu katılımcıların program geliştirmenin dört temel öğesi(hedef, içerik, eğitim durumları ve sınama durumları) olarak kategoriler altında 10 farklı temaya yönelik yansıtma kararları aldıkları görülmektedir. Katılımcıların en çok eğitim durumları üzerine yansıtma yaptıkları, sınama durumları üzerine yansıtma yapan iki, hedef ve içerik kararlarına ilişkin yansıtma yapan bir katılımcının olduğu bulunmuştur. Her bir tema için katılımcıların yansıtıcı düşüme döngülerinin 10 haftalık süreç içerisindeki durumu Tablo 3'te özetlenmiştir. 
Tablo 3. Katılımcıların Yansıtıcı Düşünme Döngüleri Süreci

\begin{tabular}{|c|c|c|c|c|c|c|c|c|c|c|c|c|c|c|c|c|c|c|c|c|c|c|c|c|c|c|c|c|c|c|c|c|c|}
\hline \multirow{3}{*}{ 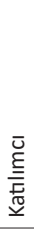 } & \multirow[t]{3}{*}{ Yansıtma Kararları } & \multicolumn{30}{|c|}{ Yansıtıcı Düşünme Döngüsü Süreci ve Bileşenler } & \multicolumn{2}{|c|}{ Toplam } \\
\hline & & \multicolumn{3}{|c|}{ 1.döngü } & \multicolumn{3}{|c|}{ 2.döngü } & \multicolumn{3}{|c|}{ 3.döngü } & \multicolumn{3}{|c|}{ 4.döngü } & \multicolumn{3}{|c|}{ 5.döngü } & \multicolumn{4}{|c|}{ 6.döngü } & \multicolumn{3}{|c|}{ 7.döngü } & \multicolumn{3}{|c|}{ 8.döngü } & \multicolumn{2}{|c|}{$\begin{array}{l}9 \\
\text { döngü }\end{array}$} & \multicolumn{3}{|c|}{ 10.döngü } & \multirow[b]{2}{*}{ v } & \multirow[b]{2}{*}{ V } \\
\hline & & $x$ & $\mathrm{Y}$ & $\mathrm{z}$ & $x$ & Y & $\mathrm{Z}$ & $\mathrm{x}$ & Y & Z & $\mathrm{x}$ & $\mathrm{Y}$ & Z & $x$ & Y & Z & $\mathrm{T}$ & $x$ & Y & $\mathrm{Z}$ & $x$ & $\mathrm{Y}$ & $\mathrm{Z}$ & $x$ & $Y$ & Z & $x$ & $Y$ & $x$ & $Y$ & $\mathrm{z}$ & & \\
\hline \multirow[t]{6}{*}{ A } & plan ve tasarım kararları & & & & 1 & & & 1 & & & 1 & & & 1 & & 1 & 1 & 1 & & & 1 & & & 1 & & & 1 & & & & & & 10 \\
\hline & $\begin{array}{l}\text { içerik seçme ve düzenleme } \\
\text { kararları }\end{array}$ & 1 & & & 1 & & & 3 & & 1 & 1 & & 1 & & & & 1 & 1 & & & & & & & & & & & & & & & 10 \\
\hline & $\begin{array}{l}\text { etkinlik ve materyal seçme } \\
\text { ve uygulama kararları }\end{array}$ & 1 & & & 1 & 2 & 1 & 1 & & & 1 & & & 1 & & & & 1 & & & 1 & & & 1 & & & & & & & & & 11 \\
\hline & $\begin{array}{l}\text { söz hakkı verme ve öğrenci } \\
\text { katlımı sağlama kararları }\end{array}$ & & & & & & & 2 & 1 & & 1 & & 1 & 3 & & & & 2 & & 2 & 1 & & & 1 & & & 1 & & & & & & 15 \\
\hline & $\begin{array}{l}\text { geribildirim verme ve hata- } \\
\text { ları düzeltme kararları }\end{array}$ & & & & 1 & & & 2 & & & 1 & 1 & & 1 & & & 1 & 1 & & & 2 & & & & 1 & & & 1 & & & & & 12 \\
\hline & $\begin{array}{l}\text { strateji, yöntem ve teknik } \\
\text { seçme ve uygulama karar- } \\
\text { ları }\end{array}$ & & & & & & & & & & 2 & & 1 & 1 & 1 & & & 1 & & & 1 & & 2 & & 1 & & 2 & & & & & & 12 \\
\hline \multirow[t]{4}{*}{ B } & $\begin{array}{l}\text { geribildirim verme ve hata- } \\
\text { ları düzeltme kararları }\end{array}$ & 1 & & & 1 & & & 3 & & & 1 & & & & & & 1 & 2 & 1 & & & 1 & & 1 & & & 1 & & 1 & 1 & & 1 & 16 \\
\hline & $\begin{array}{l}\text { etkinlik ve materyal seçme } \\
\text { ve uygulama kararları }\end{array}$ & & 1 & & & 2 & & & 2 & & & 1 & & & & & & & & & & & & & & & & & & & & & 6 \\
\hline & sınıf yönetimi kararları & 2 & 1 & & & 1 & & 2 & 1 & & 2 & 1 & & 1 & 1 & & & & 1 & & 1 & 1 & 1 & 1 & 1 & & & & & & & & 18 \\
\hline & hedeflere ulaşma kararları & 2 & 3 & & & 1 & & 1 & 2 & & 1 & 1 & & & 1 & & 1 & & 1 & & 1 & 1 & & & 2 & & & 1 & 1 & & & 1 & 21 \\
\hline \multirow[t]{2}{*}{ C } & $\begin{array}{l}\text { planlanmayan olaylar/öğ- } \\
\text { renme ürünleri kararları }\end{array}$ & 1 & 1 & & 1 & 1 & & 1 & & & 1 & & & 1 & & & & & 1 & & 2 & 1 & & & 1 & & 1 & & 1 & & & 1 & 15 \\
\hline & sınıf yönetimi kararları & 2 & 1 & & 1 & & & & 1 & & & 1 & & 3 & 1 & & & 1 & & & 1 & & & & & 1 & & 1 & & & & & 14 \\
\hline \multirow[t]{2}{*}{ D } & $\begin{array}{l}\text { sınama durumlarına zaman } \\
\text { ayırma kararları }\end{array}$ & 1 & & & 1 & & & 2 & & & 1 & & & 1 & & & & & & & & & & & & & & & & & & & 6 \\
\hline & $\begin{array}{l}\text { öğrenci motivasyonu ve sı- } \\
\text { nıf atmosferi kararları }\end{array}$ & 1 & 1 & 1 & 1 & 1 & & 1 & 1 & 1 & 3 & & 1 & 1 & 1 & 1 & & 1 & 1 & & 1 & & & 2 & & & 1 & & & 1 & 1 & 1 & 24 \\
\hline $\mathrm{E}$ & $\begin{array}{l}\text { planlanmayan olaylar/öğ- } \\
\text { renme ürünleri kararları }\end{array}$ & 3 & & & 1 & & & 1 & & & & & & 1 & 1 & 1 & & & 2 & & & & & & & & & & & & & & 10 \\
\hline $\mathrm{F}$ & $\begin{array}{l}\text { strateji, yöntem, teknik, et- } \\
\text { kinlik ve materyal seçme ve } \\
\text { uygulama kararları }\end{array}$ & 1 & 1 & & 2 & & & 1 & 1 & & 1 & & & 1 & & & 1 & 1 & 1 & & 1 & & & & 1 & & 1 & & & & & & 14 \\
\hline \multicolumn{2}{|c|}{ Toplam } & 16 & 9 & 1 & 12 & 8 & 1 & 21 & 9 & 2 & 17 & 5 & 5 & 16 & 6 & 2 & 6 & 14 & 6 & 2 & 13 & 4 & 3 & 7 & 7 & 1 & 8 & 3 & 3 & 2 & 1 & 4 & \\
\hline$\%$ & & & & & & & & & & & & & & & & & & & & & 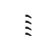 & & & & & & & & & & & & \\
\hline & & $\underset{⿱ 亠 乂}{\stackrel{f}{*}}$ & 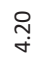 & $\stackrel{0}{o}$ & 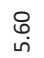 & $\stackrel{m}{\stackrel{m}{m}}$ & $\underset{0}{0}$ & $\begin{array}{l}\stackrel{+}{\infty} \\
\dot{\sigma}\end{array}$ & 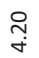 & ח̆ & $\stackrel{\text { Ș }}{n}$ & $\stackrel{m}{n}$ & $\stackrel{m}{\sim}$ & 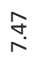 & $\stackrel{\infty}{\infty}$ & $\stackrel{n}{o}$ & 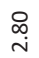 & ஸृ & 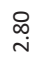 & $\stackrel{n}{\text { n़ }}$ & ì & $\begin{array}{l}\infty \\
\stackrel{\infty}{\infty} \\
i\end{array}$ & 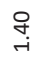 & $\stackrel{ヘ}{n}$ & $\underset{n}{\stackrel{N}{n}}$ & $\stackrel{0}{\mathscr{0}}$ & $\stackrel{m}{m}$ & $\stackrel{\substack{f \\
i}}{-}$ & $\stackrel{\circ}{\stackrel{\circ}{+}}$ & ळ̆ & $\stackrel{0}{o}$ & 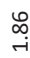 & \\
\hline
\end{tabular}

Tablo 3'te bir temayı açıklayan verilerin ilk ve son olarak hangi döngüde ve hangi yansıtıcı bileşenden elde edildiğine ilişkin bulgular özetlenmiştir. Tablo 3 incelendiğinde günlükler kathlımcıların en çok yansıtma yaptkkları bileşen$\operatorname{dir}(X=\% 59.34)$. Katılımcıların yansıtıcı düşüncelerini ifade etmelerine en çok katkıyı sağlayan bileşen günlüktür. Bunu sırasıyla görüşme formu( $\mathrm{Y}=\% 27.57)$, akran önerileri( $\mathrm{Z}=\% 8.41)$ ve algı anketleri( $\mathrm{T}=2,80, \mathrm{~V}=1,86)$ takip etmektedir.

Tablo 3 incelendiğinde, E katılımcısının "beklenmeyen/planlanmayan olayların üstesinden gelme kararları" temasını ilk olarak birinci döngüde gösterdiği, yansıtıcı düşünmeyi başlatan farkındalık durumuna ilişkin veri girişinin günlük ile başladığı görülmektedir. Benzer şekilde D katılımcısının "öğrenci motivasyonu sağlama ve sınıf atmosferi kararları" temasına ilişkin veri girişinin en son 10. döngü içerisindeki akran öneri formunda olduğu görülmektedir. Kattlımcıların bir temaya ilişkin ilk yansıtmalarının başladığı ve son yansıtmalarının görüldüğü aralıktaki haftalarda o temayla ilgili yansıtmaları devam etmiştir. Bu bağlamda temaların zamana göre dağılımlarına ilişkin bulgulara ulaşılmıştı. Tablo 2'de 
B katlımcısının "geribildirim verme ve düzeltme kararları", "hedeflere ulaşma kararları" temalarına ilişkin yansıtıcı düşünme süreci en uzun süreçlerden ikisi olup on hafta boyunca devam etmiştir. D katılımcısının "sınama durumlarına zaman ayırma kararları" temasına ilişkin yansıtıcı düşünme süreci en kısa süreç olup katılımcı eksiklerini giderdiğini düşündüğü için bu tema ile ilgili beşinci haftadan sonra yansıtma yapmamıştır.

Tablo 3'te katılımcıların temalara ilişkin yansıtmalarını yaptıkları bileşenlerin sayısı farklılık göstermektedir. Bazı katılımcılar yansıtmalarını belli bileşen ya da bileşenlerde daha yoğun olarak göstermektedir. B kathlımcısı grup görüşmelerinde işbirliği içerisinde yapılan yansıtmalara odaklandığı için "etkinlik ve materyal seçme ve düzenleme kararları" temasındaki yansıtmalarını sadece görüşme üzerinden yaparken, D katlımcısı ise bireysel yansıtma yapmaya odaklandığı için "sınama durumlarına zaman ayırma kararları" temasındaki yansıtmalarını beş haftalık süreç boyunca günlük üzerinden yapmıştır. Tüm bileşenler kullanılarak en çok sayıda (24) yansıtma yapılan yani en çok geliştirilmeye ihtiyaç duyulan tema D katılımcısının "öğrenci motivasyonu sağlama ve sınıf atmosferi kararları" temasıdır.

\section{Öğretmen Adaylarının Yansıtıcı Düşünme Süreçleri}

Görüşme, günlük ve akran geribildirimlerinden elde edilen verilerin analizinden Katılımcıların her bir öğretim uygulamasına ilişkin haftalık yansıtıcı düşünme döngüsü (farkındalık durumları, düzenleme kararları, yeniden düzenleme kararları ve sonraki uygulama planı) için aldığı kararlar sırasıyla tablolaştrıımıştı. Katılımcıların farkındalık durumları, hangi durumlar üzerine yansıtma yapmaya başladıkları ve aldıkları yansıtma kararları 10 haftalık süreç temel alınarak Tablo 4'te sunulmuştur.

\section{Tablo 4. Katilımcıların Yansıtıcı Düşünme Kararları}

\begin{tabular}{|c|c|c|c|c|c|}
\hline \multirow[t]{2}{*}{ Katılımcı } & Tema & Farkındalık & Düzenleme & $\begin{array}{l}\text { Yeniden Düzenleme Ka- } \\
\text { rarları }\end{array}$ & Sonraki Uygulama Planı \\
\hline & & Durumları & Kararları & & \\
\hline A & Plan ve tasarım kararları & $\begin{array}{l}\text {-planını etkili uygulaya- } \\
\text { mama ve kararsızlıklar } \\
\text { yaşama }\end{array}$ & $\begin{array}{l}\text {-dersi giriş, gelişme ve } \\
\text { sonuç olarak düzenle- } \\
\text { me }\end{array}$ & $\begin{array}{l}\text {-öğrenci motivasyonunu } \\
\text { sağlama }\end{array}$ & $\begin{array}{l}\text {-günlük yaşamla ilişkilen- } \\
\text { dirme }\end{array}$ \\
\hline
\end{tabular}

İçerik seçme ve düzen- -öğrencilerin dikkatlerini -dersin hedeflerini dik- -öğrenci özelliklerini leme kararları derse toplayamama ve kate alma gürültü

Etkinlik ve materyal -hazırladığı sorularda -yönergeleri daha net seçme ve uygulama ka- hata olduğunu fark etme hazırlama rarları

Söz hakkı verme ve öğ- -istenmeyen davranışla- -her öğrenciye söz hakrenci katılımı kararları rın yaşanması kı tanıma -hedeften haberdar etme

-öğrenci özelliklerini ve dersin hedeflerini dikkate alma
Geribildirim verme ve -öğrencilerin ayağa kalka- -öğrencilerden hataları düzeltme ka- rak gürültü yapması örnek isteme rarları

Strateji, yöntem ve tek- -öğretim strateji, yöntem -seçme gerekçelerini -sınıf mevcudunu dikkate nik seçme ve uygulama ve teknikleri seçmede düşünme alma kararları amaçlı davranamama
Etkinlik ve materyal -materyalini kullanırken -oğr seçme ve uygulama ka- aksaklık yaşama rarları özgün -öğrenenlere yeterli za- -öğrencilerle bireysel ilgiman tanıma lenme ve kontrol etme -sınıf mevcudu ve fiziksel koşulları dikkate -hedeflere, konuya ve içeriğe uygun seçme

-öğrenci ilgi ve ihtiyaçları doğrultusunda materyal hazırlama

Geribildirim verme ve -açıklamalarının öğrenci- -her öğrenciyi etkin kı- -bireysel ilgilenirken di- -derste ödev kontrolüne hataları düzeltme ka- ler tarafindan anlaşılama- lacak şekilde söz hakkı ğer öğrencilere farklı gö- zaman ayırma rarları ması tanıma revler verme

Sınıf yönetimi kararları -öğrencilerin sınıf içi ku- -öğrencilerin dikkatleri- -sınıf kurallarını net ola- -öğrenci özelliklerine uyralların ve yönergelere ni toplamak için sorular rak ifade etme gun olarak kesin ifadeler uymaması sorma kullanma

Hedeflere ulaşma ka- -dersin sonunda bazı he- -her cevaba geribildi- -dersi özetlemeye zaman -planı uygularken esnek rarları

ayırma

olma 


\begin{tabular}{|c|c|c|c|c|c|}
\hline Katılımcı & Tema & $\begin{array}{l}\text { Farkındalık } \\
\text { Durumları }\end{array}$ & $\begin{array}{l}\text { Düzenleme } \\
\text { Kararları }\end{array}$ & $\begin{array}{l}\text { Yeniden Düzenleme Ka- } \\
\text { rarları }\end{array}$ & Sonraki Uygulama Planı \\
\hline \multirow[t]{2}{*}{ C } & $\begin{array}{l}\text { Planlanmayan/ beklen- } \\
\text { meyen olaylar/öğren- } \\
\text { me ürünlerinin üstesin- } \\
\text { den gelme kararları }\end{array}$ & $\begin{array}{l}\text {-soyut kavramların öğren- } \\
\text { ciler tarafindan anlaşıla- } \\
\text { maması }\end{array}$ & $\begin{array}{l}\text {-öğrenci özelliklerine } \\
\text { uygun somut kelimeler } \\
\text { seçme }\end{array}$ & $\begin{array}{l}\text {-istenmeyen davranışı } \\
\text { görmezden gelme }\end{array}$ & $\begin{array}{l}\text {-sınıf içi kuralları ve yö- } \\
\text { nergeleri net olarak derse } \\
\text { girişte ifade etme }\end{array}$ \\
\hline & Sınıf yönetimi kararları & -gürültü olması & $\begin{array}{l}\text {-yönergeleri net olarak } \\
\text { belirleme }\end{array}$ & $\begin{array}{l}\text {-etkinliği hazırlarken sı- } \\
\text { nıfin fiziksel durumunu, } \\
\text { mevcudunu dikkate alma }\end{array}$ & $\begin{array}{l}\text {-materyal hazırlamada } \\
\text { somutluk ve uygulanabi- } \\
\text { lirliğe dikkat etme }\end{array}$ \\
\hline \multirow[t]{2}{*}{ D } & $\begin{array}{l}\text { Öğrenci motivasyonu ve } \\
\text { sınıf atmosferi kararları }\end{array}$ & $\begin{array}{l}\text {-öğrencilerin dikkatlerini } \\
\text { derse toplayamama }\end{array}$ & $\begin{array}{l}\text {-öğrenci seviyesine uy- } \\
\text { gun gösrsel ile derse } \\
\text { başlama }\end{array}$ & $\begin{array}{l}\text {-öğrenciler arası bilgi alış- } \\
\text { verişini destekleme }\end{array}$ & $\begin{array}{l}\text {-ders tasarımına ilişkin } \\
\text { hatırlatıcı notlar alma }\end{array}$ \\
\hline & $\begin{array}{l}\text { Sınama durumlarına za- } \\
\text { man ayırma kararları }\end{array}$ & $\begin{array}{l}\text {-özetleme yapamadan } \\
\text { dersi bitirmek zorunda } \\
\text { kalma }\end{array}$ & -zamanı kontrol etme & $\begin{array}{l}\text {-planı uygularken esnek } \\
\text { davranma }\end{array}$ & $\begin{array}{l}\text {-dersi değerlendirme için } \\
\text { zaman ayırma }\end{array}$ \\
\hline$E$ & $\begin{array}{l}\text { Planlanmayan/ beklen- } \\
\text { meyen olaylar/öğren- } \\
\text { me ürünlerinin üstesin- } \\
\text { den gelme kararları }\end{array}$ & $\begin{array}{l}\text {-öngörülemeyen öğrenci } \\
\text { cevaplarına geribildirim } \\
\text { vermede çaresiz hissetme }\end{array}$ & $\begin{array}{l}\text {-öngörülemeyen ce- } \\
\text { vaplarla ilgili diğer öğ- } \\
\text { rencilerden fikir isteme }\end{array}$ & $\begin{array}{l}\text {-tartş̧ma ortamı oluştu- } \\
\text { rup doğru cevaba sorgu- } \\
\text { lamalar ile ulaşılmasını } \\
\text { sağlama }\end{array}$ & $\begin{array}{l}\text { - tartışma ortamı oluş- } \\
\text { turma ve fikir alışverişini } \\
\text { destekleme }\end{array}$ \\
\hline $\mathrm{F}$ & $\begin{array}{l}\text { Strateji, yöntem teknik, } \\
\text { etkinlik ve materyal } \\
\text { seçme ve uygulama ka- } \\
\text { rarları }\end{array}$ & $\begin{array}{l}\text {-sınıf yönetimini sağla- } \\
\text { makta zorlanma }\end{array}$ & $\begin{array}{l}\text {-görsel materyal kul- } \\
\text { lanma }\end{array}$ & $\begin{array}{l}\text {-not aldırma } \\
\text {-kavram karikatürü kul- } \\
\text { lanma }\end{array}$ & $\begin{array}{l}\text {-farklı disiplinlerle ilişki- } \\
\text { lendirme yapma }\end{array}$ \\
\hline
\end{tabular}

Tablo 4'te verilen temalar arasından A katılımcısının içerik seçimi ve düzenlemesi yapma temasını en iyi açıklayan alıntılara yer verilmiştir. Katılımcının dersin hedeflerini ve öğrenci özelliklerini göz önünde bulundurarak içerik seçimi ve düzenlemesini yapma konusunda zorlandığı birinci hafta görüşme kayıtlarına şu şekilde yansımıştır: "Bazılarına sorular çok basit geldi. Cevapları çabuk bulduklarından gürültü yapmaya başladılar. Sınıf seviyesini göre farklı sorular hazırlardım.". Üçüncü hafta günlüğünde, ders içeriğini hazırlarken öğrenci özelliklerini yeterince dikkate almadığı için sınıfta gürültü olduğunu "Etkinliğin 10 dakika sürmesini planlamıştım ama 5 dakika sonra gürültü başladı. Etkinliği yarıda bırakmak zorunda kaldım." şeklinde ifade etmiştir. Dördüncü hafta öğretmen adayının dersini gözlemleyen bir akranın bu durumda farklı neler yapılabileceğine ilişkin önerisi "Öğrenciler biliyor olsalar bile bir adım öteye taşımak için kıyaslamalar yapmalarını sağlayabilirdi." şeklindedir. Katılımcının ileriki haftalarda dersin hedeflerini ve öğrenci özelliklerini göz önünde bulundurarak içerik seçimi ve düzenlemesi yaptgğı görülmektedir. Katlımcı, altıncı hafta günlüğünde, ileriki uygulamalarında öğrenci özelliklerini dikkate aldığında, öğrencilerden gelen geribildirimlere göre iyileşme olduğuna karar verdiğini "Öğrencilere sorduğum sorulara ilgiyle cevap veriyor ve derse katllıyorlarsa planladığım dersin içeriği uygundur" şeklinde belirtmiştir. Görüşme, günlük ve akran geribildirimleri analiz edildiğinde öğretmen adayının sonraki öğretim uygulamalarında dersin hedeflerini dikkate aldığı, sınıf düzeyini de göz önünde bulundurarak içerik seçimi ve düzenlemesi yaptı̆̆ ve alt haftalık süreç sonucunda ilk haftalara göre öğrenci ilgi ve ihtiyaçlarını daha çok dikkate aldığına ulaşılmıştr.

Tablo 4 incelendiğinde, B katılımcısının ilk haftalarda hedeflere ulaşma kararlarıyla ilgili olarak, yeterince geribildirim vermemesinden kaynaklanan aksaklıklar yaşadığı görülmektedir. Katılımcı süreçte geribildirim vererek bu aksaklıkları gidermek için dersi özetlemeye zaman ayırma, planı uygularken esnek olma gibi yeniden düzenleme ve sonraki planını uygulama kararları almıştır. C katılımcısının etkinlikler sırasında planlanmayan öğrenci davranışlarının üstesinden gelmek için öğrenci özelliklerine uygun somut açıklama yapma, istenmeyen davranışı görmezden gelme gibi yeniden düzenleme kararları almıştr. Dersinin planladığı gibi ilerlemesi için yönergeleri net olarak derse girişte ifade etmenin önemi üzerine yansıtmalar yapmıştır. D katılımcısının öğrencilerin dikkatlerini derse toplayamaması ve "...biteceğini ögrencilere hissettirerek dersi özetleyip değerlendirebilseydim daha verimli ve etkili olurdu" ifadesinden özetleme yapamadan dersi bitirmek zorunda kalması durumlarında rahatsızlık hissetmesi üzerine yansıtmalar yapttğı görülmektedir. Öğrencilerin dikkatlerini derse toplama konusunda daha amaçlı davranmak için düzenleme kararları aldığı "Videolar öğrencileri derse iyi motive etti..." ifadesinden belirlenmiştir. Öğretim uygulamalarında öğrenciler arası bilgi alışverişini destekleme konusunda yeniden düzenleme kararları alarak sonraki uygulama planlarına aldığı kararları yansıttğı görülmektedir. E katıımcısının ilk haftalarda, öğretim süreçlerinde karşılaştı̆̆ı öngörülemeyen öğrenci cevaplarına geribildi- 
rim vermede çaresizlik hissetmesi üzerine ilerleyen haftalarda, sınıf içi kuralları ve yönergeleri net olarak belirleyerek derse girişte ifade etme, tartş̧ma ortamı oluşturup doğru sonuca sorgulamalarla ulaşılmasını sağlama ve ayrıntılı açıklamalar yapma konularında yansıtmalar yaptığı görülmektedir. F katılımcısının görsel materyal kullanma, not aldırma, kavram karikatürü kullanma gibi düzenleme ve yeniden düzenleme kararları aldığı belirlenmiştir.

\section{Yansıtıcı Düşünme Becerilerinin Gelişimine Katkı Sağlayan Faktörler}

Faktörler katılımcıların yansıtıcı bileşenlerle ilgili algı anketlerindeki ifadelerini10 haftalık süreçte gerçekleştirme durumlarının diğer veri kaynaklarından elde edilen verilerle kontrol edilerek doğrulanması ile bulunmuştur. Bu faktörler Şekil 1'de sunulmuştur.

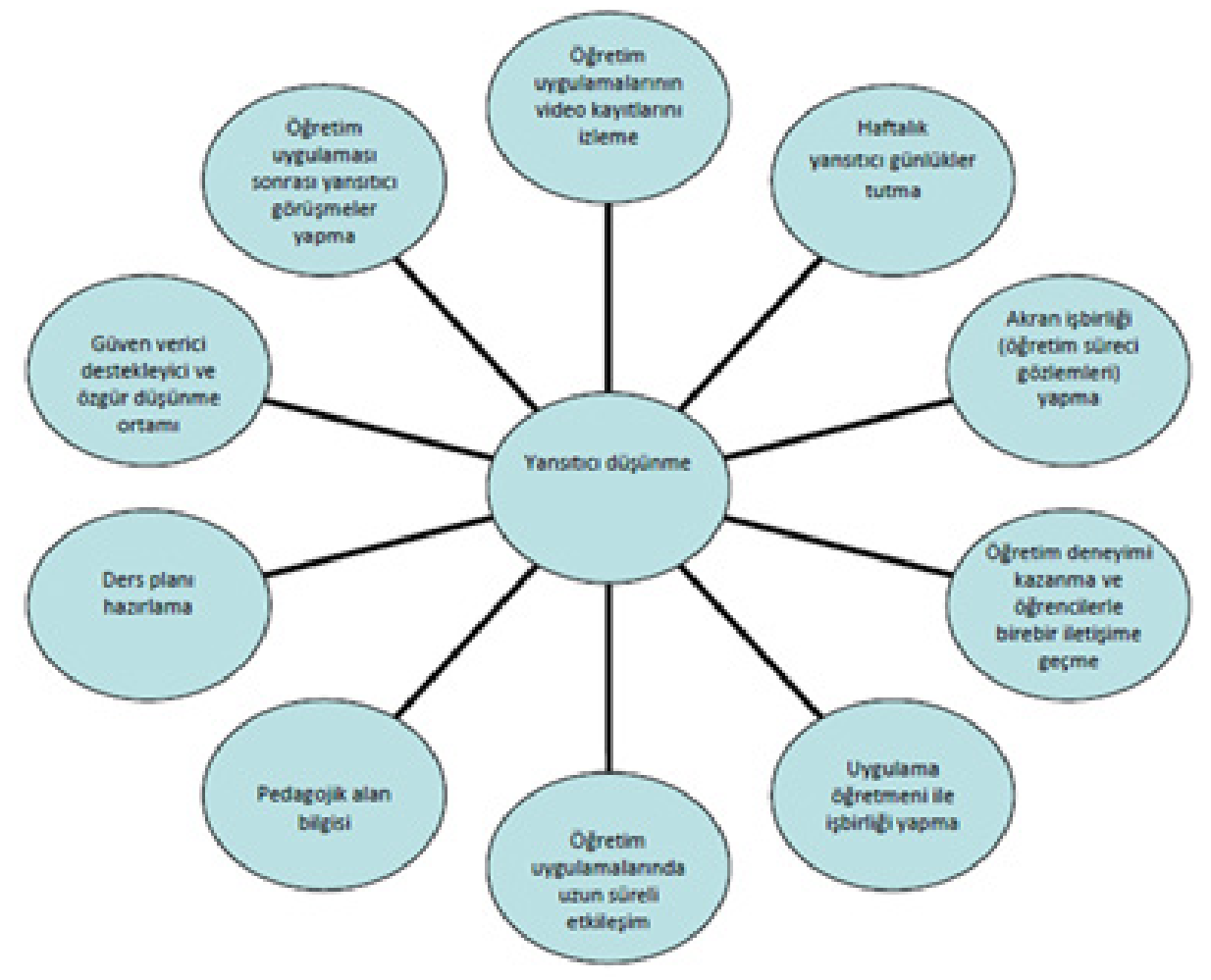

\section{Şekil 1. Yansıtıcı düşünme becerilerinin gelişimine katkı sağlayan faktörler}

Şekil 1'de öğretim uygulamaları sonrasında yapılan görüşmelerin katılımcıların yansıtıcı düşünme becerilerinin gelişimini desteklediğini düşündükleri belirlenmiştir. Katılımcıların bu sayede öğretim süreçlerini değerlendirip sonraki dersin tasarımına yönelik kararlar aldıklarını belirten ifade "Görüşmelerde o hafta yaptıklarımızı değerlendirip diğer haftaya nasıl bir plan yapacağımızı sorguluyoruz. Eksiklerimizi fark ederek düzeltmeye çalışıyoruz." şeklindedir. Katılımcıların düzenli günlük tutarak ders boyunca yaptıklarını sorgulama ve değerlendirme firsatı bulduklarını düşündükleri belirlenmiştir. Buna ilişkin ifade "Yaptıklarımı değerlendirmemi ve haftaya daha iyi performans sergilememi sağlıyor. Uygulama sürecini tekrar düşünüyorum ve iyileştirmeye çalışıyorum." şeklindedir. Katlımcıların uygulamalar sırasında farkına varamadıkları yönlerinin videolar sayesinde daha net bir şekilde görülebildiklerini belirten ifade "Videoyu izlediğimde kendimi daha objektif görebiliyorum. Ders süresince öğrencilerle iletişimimi, olumlu ve olumsuz yönlerimi izleme firsat buldum." şeklindedir. Birbirlerinin öğretim deneyimlerine katılan öğretmen adaylarının önerilerini akranları ile paylaşmalarının olumlu sonuçlarını gösteren ifade "Akran önerileri, işbirliği içerisinde birbirimizi değerlendirmemizi, önerilerde bulunmamızı, farkında olmadığımız eksiklerimizi görmemizi ve tamamlamamızı sağladı." şeklindedir.

\section{Tartışma}

Öğretmen adaylarının öğretim uygulamalarına ilişkin program geliştirmenin dört temel öğesi olan hedef, içerik, eğitim durumları ve sınama durumları olarak kategoriler altında 10 farklı temaya yönelik yansıtma kararları aldıkları sonucuna ulaşılmıştır. Ayrıca eğitim durumlarının diğer boyutlara göre çok fazla bileşeni içermesi sebebiyle bu boyuta yoğunlaşarak yansıtma yapmakta oldukları sonucuna ulaşılmıştır. Yapılan çalışmalar incelendiğinde öğretmen adaylarının öğretim programının dört bileşenine yönelik yansıtma kararları aldıkları ve öğretme-öğrenme sürecine ilişkin öğrenme- 
yi kolaylaştrma, öğrenmenin niteliği ve strateji, yöntem ve tekniklerin işe koşulması boyutlarında yansıtma yaptıkları elde edilmiştir (Erginel, 2006; Köksal ve Demirel, 2008). Bu araştırmada eğitim durumlarına ilişkin strateji, yöntem ve teknik seçimi, sınıf atmosferi ve öğrenci güdülenmesi üzerine yoğunlaşarak yansıtma kararları almaları öğretmen adaylarının ne gibi durumlar üzerine yansıtma yaptıklarına ilişkin araştırma sonuçlarını bir anlamda teyit etmiştir.

Öğretmen adaylarının yansıtıcı düşünme süreçleri incelendiğinde nasıl yansıtma yaptıkları ile ilgili sonuçlara ulaşılmıştır. Araştırmada katılımcılarda yansıtmayı başlatan etkenlerin öğretim süreçleri sırasında gürültü olması, planlanmayan öğrenme ürünlerinin olması, sınıf yönetimini sağlamakta zorlanılması gibi rahatsızlık algıları olduğu sonucuna ulaşılmıştır. Bu sonuç, yansıtmanın başlamasına sebep olan etkenlerin çaresizlik hissetme, planlanmayan durumlar karşısında çatı̧̧ma yaşama gibi etkenler olduğunu sonuçları ile benzerlik göstermektedir (Clarke, 1995).

Araştırmada öğretmen adaylarının yansıtmayı başlatan etkenler olan rahatsızlık algılarının üstesinden gelmek için o konuda düzenleme, yeniden düzenleme ve sonraki uygulamalar için tasarım kararları aldıkları görülmüştür. Yapılan çalışmalar incelendiğinde öğretmen adaylarının dersi planlama ve içeriği seçme konularında düzenleme kararları alırken öğrenci özelliklerini ve dersin hedeflerini dikkate aldıkları belirlenmiştir (Koç ve Yıldız, 2012; Köksal ve Demirel, 2008). Bu çalışmada dersin hedeflerine ulaşma ile ilgili düzenleme kararlarının alınmasında bir önceki dersin planlarının etkili olduğu ve dersin içeriği ile ilgili kararlarda öğrenci özelliklerinin ve dersin hedeflerinin dikkate alındığı sonucuna ulaşılmış olması diğer çalışmalarda varılan çıkarımları desteklemektedir. Ayrıca öğretmen adaylarının sınama durumlarıyla ilgili yansıtma yaparken dersi özetlemeyi, değerlendirmeye zaman ayırmayı ve zamanı etkili kullanmayı sağlayacak düzenleme ve sonraki uygulamalar için tasarım kararları aldıkları sonucuna ulaşılmıştır. Bu sonuçlar sınama durumlarıyla ilgili yansıtma yapılırken öğretim yöntemleri, öğrenci güdülenmesi, sınıf yönetimi dikkate alınarak öğretim uygulamasında düzenleme ve sonraki uygulamalar için tasarım kararlarının alındığı araştırma sonuçlarını desteklemektedir (Erginel, 2006; Köksal ve Demirel, 2008; Ünver, 2001).

\section{Yansıtıcı Düşünme Becerilerinin Gelişimine Katkı Sağlayan Faktörler}

Öğretmen adaylarının yansıtıcı düşünme becerilerinin gelişimini destekleyen 10 faktörün; öğretim uygulamalarının video kaydı, yansıtıcı günlükler, akran işbirliği, öğretim deneyimi, uygulama öğretmeniyle işbirliği, ders planı hazırlama, öğretim uygulaması sonrası yapılan görüşmeler, öğretim uygulamalarında uzun süreli iletişim, güven verici ve destekleyici düşünme ortamı, pedagojik alan bilgisi olduğu sonucuna ulaşıımıştr. Öğretmen adaylarının uygulama süreci boyunca özgün öğretim ortamlarında bulunmalarının ve birebir deneyim kazanmanın, akran gözlem ve önerilerinin, öğretim uygulamalarından sonra gerçekleştirilen görüşmeler sırasındaki etkileşimin, haftalık tutulan günlüklerin ve uygulama öğretmeni tarafindan yapıcı yönlendirmenin yansıtıı düşünmenin gelişimine katkı sağladığı belirlenmiştir. Bu sonuçlar, öğretim uygulamalarına ilişkin video kayıtları kullanmanın, günlük tutmanın, akran, öğrenci ve uygulama öğretmeni ile iletişimin, yansıtma için yeterli zamanın, geçmiş uygulamaları değerlendirmenin, güven verici ve destekleyici ortamın yansıtıı düşünmenin gelişimine katkı sağladığı yönünde diğer çalışmalarda varılan çıkarımları desteklemektedir (Clarke, 1995; Eröz-Tuğa, 2013; Fazaklı ve Kuru Gönen, 2017; Taggart ve Wilson, 2005). Ayrıca bu çalışmada katılımcıların her hafta öğretim uygulaması yaparak aktif bir öğretme etkinliğinde bulunmaları öğretim deneyimi kazanmanın yansıtıcı düşünmenin gelişimini destekleyen faktör olduğu sonucunu bir anlamda teyit etmiştir (Moon, 2006; King, Goodson ve Rohani, 2013).

Bu çalışmada kathlımcıların yansıtıcı düşünmelerine ve bu düşüncelerini ifade etmelerine en çok katkıyı sağlayan bileşenin günlük olduğu ve bunu sırasıyla görüşme formu, akran önerileri ve algı anketlerinin takip ettiği sonucuna ulaşılmıştır. Öğretmenler ve öğrenciler açısından yansıtıcı araçların etkinliğine yönelik çalışmada, günlüğün en etkili araç olduğu bunu sırasıyla akran gözlemi ve öğrenci geri bildirimlerinin izlediği ayrıca en az etkili olan aracın ses kaydı olduğu bulunmuştur (Fatemipour, 2013). Bu araştırma günlüğün en etkili araç olduğunu teyit etmiş fakat diğer bileşenler ve bunların sırasında farklılık ortaya koymuştur.

Görüşmelerin öğretmen adaylarının bu görüşmeler sırasında öğretim süreçlerini değerlendirerek bir sonraki dersin tasarımına yönelik kararlar almalarını sağlaması açısından yansıtıcı düşünme becerilerinin gelişimini desteklediği sonucuna ulaşılmıştır. Ayrıca görüşmeler sırasında yapılan yansıtmalarda işbirliğinin önemli olduğu olduğu ve katılımcıların işbirliğine dayalı yansıtmalar yaptıkları sonucuna ulaşılmıştır. Diğer çalışmalarda işbirliğine dayalı deneyimlerin paylaşıldığı ortamlarda yansıtıı düşünmeye yönelik benzer sonuçlara ulaşılmıştır (Bağcıoğlu, 1999; Stoddard, 2002). Yapılan çalışmalar incelendiğinde günlüklerin yansıtıcı düşünme becerilerinin gelişimine katkı sağladığı elde edilmiştir (Burton, 2009; Can ve Altuntaş, 2016; Farrah, 2012; Fazaklı ve Kuru-Gönen, 2017; Graham, 2003; Halim, Buang, and Meerah, 2010; Roskos, 2001; Ünver, 2003; Walker, 2006). Bu çalışmada günlükler her hafta katılımcıların öğretim uygulamasından sonra kullanılmış olup sonuçlar günlüklerin öğretim uygulaması boyunca yapılanları sorgulamayı ve değerlendirmeyi sağladığını göstermiştir. Bu yönüyle çalışma günlüklerin yansıtıcı düşünmenin gelişimini desteklediğini teyit etmiştir. 
Yapılan çalışmalar incelendiğinde öğretim uygulamalarının diğer öğretmen adayları tarafindan gözlemlenerek değerlendirilmesinin ve derslerin video kayıtlarının izlenmesinin birçok boyutun farkında olunmasını sağladığı sonuçlarına ulaşılmıştır (Clarke, 2003; Eröz-Tuğa, 2013; Fazaklı ve Kuru-Gönen, 2017; Göde, 1999; Lakshmi, 2014). Bu çalışmada her hafta öğretim uygulamaları akranlar tarafindan gözlemlenmiş ve videoya kaydedilerek katılımcıların kendileri tarafindan izlenmiştir. Sonuçlar akran önerilerinin ve video kayıtlarının katılımcıların uygulama sırasında farkında olamadıkları yönlerini ortaya çıkararak ileriki derslerde bu yönleri geliştirme firsatı sunduğunu göstererek bu yönüyle yansıtıcı düşünmenin gelişimini destekleyen faktörler olmalarını bir anlamda desteklemektedir.

Yansıtıcı düşünmenin gelişimine katkı sağlayan faktörler ile ilgili sonuçlar, yansıtıcı düşünmenin uzun zaman dilimlerinde, çoklu sınıflar ve kişiler arası etkileşim ile geliştirilebileceğini göstermektedir (Clarke, 2003). Bu çalışmada güven veren, destekleyici ve özgür düşünme ortamının ve öğretmen adaylarının pedagojik alan bilgilerinin uygulamalarında karşılaştıkları problemleri çözmelerini sağlayarak yansıtıcı düşünme becerilerinin gelişimine katkı sağladığı sonucuna ulaşılmıştır. Sonuçlar işbirliği ve destekleyici ortamların yansıtmaya olumlu etkisi ile ilgili araştırma sonuçlarını desteklemektedir.

Araştırma sonuçlarına bağı olarak yansıtıcı düşünme becerilerini geliştiren faktörlerin dikkate alınması ve öğretmen adaylarının yansıtıcı düşünme becerilerini daha kapsamlı ortaya koyulması için öğretmen adayı, fakülte ve okul işbirliği içerisinde uzun süreli çalışmalar yapılması önerilmektedir. Ayrıca öğretmen adaylarının yansıtıcı düşünme becerilerine hangi düzeyde sahip olduklarına ve bu becerileri hangi düzeyde kullandıklarına ilişkin çalışmalar yapılması önerilmektedir.

\section{Kaynakça}

Adler, S. (1991). The reflective practitioner and curriculum of teacher education. Journal of Education for Teacher, 17(2), 139-151.

Akbari, R.(2007). Reflections on reflection: A critical appraisal of reflective practices in L2 teacher education. System, 35(2), 192207.

Bağcıoğlu, G. (1999). Öğretmen adaylarında yansıtıcı düşünmeyi geliştirici etkinlikler.8. Ulusal Eğitim Bilimleri Kongresi, Karadeniz Teknik Üniversitesi, Trabzon.

Bartlett, S. ve Burton, D. (2006). Practitioner research or descriptions of classroom practice? A discussion of teachers investigating their classrooms. Educational Action Research, 14(3), 395-405.

Bigge, M. L. ve Shermis, S. S. (1999). Learning theories for teachers. New York: Longman Inc.

Brockbank A. ve McGill I. (2000). Facilitating reflective learning in Higher Education, Buckingham: SRHE/Open University Press

Brookfield, S. (1995) Becoming a critically reflective teacher. San Francisco: Jossey-Bass.

Burton, J. (2009). Reflective writing: Getting to the heart of teaching and learning. J. Burton, P. Quirke, C. L. Reichmann ve J. K. Peyton (Ed.), Reflective writing: A way to lifelong teacher learning (s. 1-11) içinde. USA: TESL-EJ Publications.

Can, R. ve Altuntaş, B. (2016). Yansıticı günlük yazma uygulamasına ilişkin öğrenci görüşleri. Ana Dili Eğitimi Dergisi, 4(1), 53-63.

Clarke, A. (1995). Professional development in practicum settings: Reflective practice under scrutiny. Teaching and Teacher Education, 11(3), 243-61.

Clarke, A. (2003) The nature and substance of cooperating teacher reflection. Teaching and Teacher Education, 22, 910-921.

Dewey, J. (1933). How we think: A restatement of the relation of reflective thinking to the educative process. New York: D.C. Heath and Company.

Dolapçığlu, S. D. (2007), Sınıf öğretmenlerinin yansıtıı düşünme düzeylerinin değerlendirilmesi, Yüksek Lisans Tezi, Mustafa Kemal Üniversitesi Sosyal Bilimler Enstitüsü, Hatay.

Ekiz, D. (2006). Kendini ve başkalarını izleme: Sınıf öğretmeni adaylarının yansıtıcı günlükleri. ilköğretim Online, 5(1), 45-57.

Erginel, Ş. S. (2006). Developing reflective teachers: A study on perception and improvement of reflection in pre-service teacher education. Yayımlanmamış Doktora Tezi, Orta Doğu Teknik Üniversitesi: Ankara.

Eröz-Tuğa, B. (2013). Reflective feedback sessions using video recordings. ELT Journal, 67(2), 175-183.

Farrah, M. (2012). Reflective journal writing as an effective technique In the writing process. An-Najah University Journal for Research - Humanities, 26(4), 997-1025.

Fatemipour, H. (2013). The efficiency of the tools used for reflective teaching in ESL contexts. Procedia-Social and Behavioral Sciences, 93, 1398-1403.

Fazaklı, Ö. ve Kuru Gönen, S. İ. (2017). Yansıtma üzerine yansıtma: İngilizceyi yabancı dil olarak öğreten üniversite okutmanlarının yansıtmalı öğretim uygulamaları üzerine algıları. Hacettepe Üniversitesi Eğitim Fakültesi Dergisi, 32(3), 708-726.

Ferraro, J. M. (2000). Reflective practice and professional development. ERIC Digest ED449120. Erişim tarihi: 2 Mart 2017, http:// searcheric.org/digests/ed449120.html

Göde, Ü. (1999). Teacher reflection through self-observation. Yayımlanmamış Yüksek Lisans Tezi, Bilkent Üniversitesi, Ankara. 
Graham. L. (2003). Writing journals: An investigation. Reading Literacy and Language, 37(1), 39-42.

Gün, B. (2011). Quality self-reflection through reflection training. ELT Journal, 65(2), 126-135.

Halim, L., Buang, N.A. ve Meerah, T.S.M. (2010).Guiding student teachers to be reflective. Procedia-Social and Behavioral Sciences, 18, 544-550.

Jay, J.K. ve Johnson, K.L. (2002). Capturing complexity: a typology of reflective practice for teacher education. Teaching and Teacher Education, 18, 73-85.

Johnson, A. P. (2010). A short guide to action research. Boston: Ally and Bacon.

Kember, D., Jones, A., Loke, A. Y., Mckay, J., Sinclair, K., Tse, H., Webb, C., Wong, F. K. Y., Wong, M. ve Yeung, E. (1999). Determining the level of reflective thinking from students' written journals using a coding scheme based on the work of Mezirow. International Journal of Lifelong Education, 18(1), 18- 30.

Kızılkaya, G., Aşkar, P. (2009). Problem çözmeye yönelik yansıtıcı düşünme becerisi ölçeğinin geliştirilmesi. Eğitim ve Bilim, 34(154), 82-92.

Koç, C. ve Yıldız, H. (2012). Öğretmenlik Uygulamasının Yansıtıcıları: Günlükler. Eğitim ve Bilim, 37(164), $223-236$.

Korumaz, M. ve Karakaş, A. (2014). İngilizce Okutmanlarının Yansıtıcı Öğretime Yönelik Tutumlarının İncelenmesi. Pegem Eğitim ve Öğretim Dergisi, 4(1), 27-46.

Köksal, N. ve Demirel, Ö. (2008). Yansıtıcı Düşünmenin Öğretmen Adaylarının Öğretmenlik Uygulamalarına Katkıları, Hacettepe Üniversitesi Eğitim Fakültesi Dergisi, 34, 189-203.

Lakshmi, S.B. (2014). Reflective practice through journal writing and peer observation: A case study. Turkish Online Journal of Distance Education, 15(4), 189-204.

Landis, J. R. ve Koch, G. G. (1977). The measurement of observer agreement for categorical data. Biometrics, 33, $159-174$.

Moon, J. A. (2006). Learning journals: Handbook for reflective practice and professional development. London: Routledge.

Opp-Beckman, L. ve Klinghammer, S. J., (2006). Shaping the way we teach English: Successful practices around the world. Washington: Office of English Language Programs

Rodgers, C. (2002). Defining reflection: Another look at John Dewey and reflective thinking. Teachers College Record, 104 (4), 842-866.

Schön, D.A. (1987). Educating the Reflective Practitioner. San Francisco: Jossey- Bass.

Schön, D. A. (1983). The reflective practitioner: How professionals think in action. New York: Basic Books.

Shoffner, M. (2008). Informal reflection in pre-service teacher education, Reflective Practice, 9(2), $123-134$.

Stoddard, S. (2002). Reflective thinking within an art methods class for preservice elementary teachers. Hawaii International Conference on Education, Hawaii, Erişim tarihi: 12 Ocak 2017, http://www.hiceducation.org/edu_proceedings/Shari\%20S.\%20 Stoddard2.pdf.

Taggart, G. L. ve Wilson, A. P. (2005). Promoting reflective thinking in teachers: 50 action strategies. California: Corwin Press.

Ünver, G. (2003). Yansıticı düşünme. Ankara: Pegem A Yayıncılık.

Walker, S. E. (2006). Journal writing as a teaching technique to promote reflection. Journal of Athletic Training, 42(2), $216-221$.

Wubbels, T. ve Korthagen, F. (1990) The effects of a pre-service teacher education program for the preparation of reflective teachers, Journal of Education for Teaching, 16, 29-43.

YÖK (1999). Aday Öğretmen Kılavuzu. Ankara: YÖK Dünya Bankası Yayınları. 


\section{Ekler}

Ek 1. Veri toplama süreci ve yansıtıcı bileşenler

\begin{tabular}{|c|c|c|c|c|}
\hline Hafta & İçerik & Yapılanlar & Yansıtıcı Bileşenler & Veri toplama araçları \\
\hline 1.hafta & Oryantasyon & $\begin{array}{l}\text {-Okul ziyareti } \\
\text {-Uygulama öğretmeni } \\
\text { ile tanışma. } \\
\text { - Uygulama süreci hak- } \\
\text { kında genel bilgilendir- } \\
\text { me. }\end{array}$ & & \\
\hline 2.hafta & Planlama & $\begin{array}{l}\text {-Dersleri planlanma. } \\
\text {-Dönem planı. } \\
\text {-Öğretim uygulamaları- } \\
\text { nı planlama. }\end{array}$ & $\begin{array}{l}\text {-Yansıtıcı bileşenlerin (günlükler, video kayıt- } \\
\text { ları, görüşmeler, akran önerileri, algı anket- } \\
\text { leri) tanıtımı, planlaması. }\end{array}$ & \\
\hline $\begin{array}{l}\text { 3. hafta } \\
\text { (1. günlük } \\
\text { haftası) }\end{array}$ & $\begin{array}{l}\text { Dersi planla- } \\
\text { ma ve etkin- } \\
\text { likleri sıraya } \\
\text { koyma }\end{array}$ & $\begin{array}{l}\text {-Öğretim uygulaması } \\
\text { yapma ve yansıtma }\end{array}$ & $\begin{array}{l}\text { - Öğretim uygulamasını kayıt(video) altına } \\
\text { alma } \\
\text {-Yansıtıcı görüşme yapma } \\
\text {-Günlükleri teslim etme } \\
\text {-Akran önerileri yazma }\end{array}$ & $\begin{array}{l}\text {-Video kaydı } \\
\text {-Görüşme formu ve ses kayıt- } \\
\text { ları } \\
\text {-Akran geribildirim formları }\end{array}$ \\
\hline $\begin{array}{l}\text { 4.hafta } \\
\text { (2. günlük } \\
\text { haftası) }\end{array}$ & $\begin{array}{l}\text { Dersin yöne- } \\
\text { timi ve sınıf } \\
\text { kontrolü }\end{array}$ & $\begin{array}{l}\text {-Öğretim uygulaması } \\
\text { yapma ve yansıtma }\end{array}$ & $\begin{array}{l}\text { - Öğretim uygulamasını kayıt(video) altına } \\
\text { alma } \\
\text {-Yansıtıcı görüşme yapma } \\
\text {-Günlük geribildirimleri ve yeniden teslim } \\
\text { etme } \\
\text {-Akran önerileri yazma }\end{array}$ & $\begin{array}{l}\text {-Video kaydı } \\
\text {-Görüşme formu ve ses kayıt- } \\
\text { ları } \\
\text {-Yansıticı günlükler } \\
\text {-Akran geribildirim formları }\end{array}$ \\
\hline $\begin{array}{l}\text { 5.hafta } \\
\text { (3. günlük } \\
\text { haftası) }\end{array}$ & $\begin{array}{l}\text { Öğretimde } \\
\text { sorulardan } \\
\text { yararlanma }\end{array}$ & $\begin{array}{l}\text {-Öğretim uygulaması } \\
\text { yapma ve yansıtma }\end{array}$ & $\begin{array}{l}\text { - Öğretim uygulamasını kayıt(video) altına } \\
\text { alma } \\
\text {-Yansıtıcı görüşme yapma } \\
\text {-Günlük geribildirimleri ve yeniden teslim } \\
\text { etme } \\
\text {-Akran önerileri yazma }\end{array}$ & $\begin{array}{l}\text {-Video kaydı } \\
\text {-Görüşme formu ve ses kayıt- } \\
\text { ları } \\
\text {-Yansıtıcı günlükler } \\
\text {-Akran geribildirim formları }\end{array}$ \\
\hline $\begin{array}{l}\text { 6.hafta } \\
\text { (4. günlük } \\
\text { haftası) }\end{array}$ & $\begin{array}{l}\text { Ders kitapları } \\
\text { ve yardımcı } \\
\text { kaynakları } \\
\text { etkili kullan- } \\
\text { ma }\end{array}$ & $\begin{array}{l}\text {-Öğretim uygulaması } \\
\text { yapma ve yansıtma }\end{array}$ & $\begin{array}{l}\text { - Öğretim uygulamasını kayıt(video) altına alma } \\
\text {-Yansıtıcı görüşme yapma } \\
\text {-Günlük geribildirimleri ve yeniden teslim } \\
\text { etme } \\
\text {-Akran önerileri yazma }\end{array}$ & $\begin{array}{l}\text {-Video kaydı } \\
\text {-Görüşme formu ve ses kayıt- } \\
\text { ları } \\
\text {-Yansıticı günlükler } \\
\text {-Akran geribildirim formları }\end{array}$ \\
\hline
\end{tabular}




\begin{tabular}{|c|c|c|c|c|}
\hline Hafta & İçerik & Yapılanlar & Yansıtıcı Bileşenler & Veri toplama araçları \\
\hline $\begin{array}{l}\text { 7.hafta } \\
\text { (5. günlük } \\
\text { haftası) }\end{array}$ & $\begin{array}{l}\text { Çalışma yap- } \\
\text { rakları hazır- } \\
\text { lama } \\
\text { ve kullanma }\end{array}$ & $\begin{array}{l}\text {-Öğretim uygulaması } \\
\text { yapma ve yansıtma }\end{array}$ & $\begin{array}{l}\text { - Öğretim uygulamasını kayıt(video) altına alma } \\
\text {-Yansıtıcı görüşme yapma } \\
\text {-Günlük geribildirimleri ve yeniden teslim } \\
\text { etme } \\
\text {-Akran önerileri yazma } \\
\text {-Uygulama ortası algı anketlerini uygulama }\end{array}$ & $\begin{array}{l}\text {-Video kaydı } \\
\text {-Görüşme formu ve ses kayıt- } \\
\text { ları } \\
\text {-Yansıtıcı günlükler } \\
\text {-Akran geribildirim formları }\end{array}$ \\
\hline $\begin{array}{l}\text { 8. hafta } \\
\text { (6. günlük } \\
\text { haftası) }\end{array}$ & $\begin{array}{l}\text { Grupla ve } \\
\text { eşli çalışma- } \\
\text { lar yapma }\end{array}$ & $\begin{array}{l}\text {-Öğretim uygulaması } \\
\text { yapma ve yansıtma }\end{array}$ & $\begin{array}{l}\text { - Öğretim uygulamasını kayıt(video) altına } \\
\text { alma } \\
\text {-Yansıtıcı görüşme yapma } \\
\text {-Günlük geribildirimleri ve yeniden teslim } \\
\text { etme } \\
\text {-Akran önerileri yazma }\end{array}$ & $\begin{array}{l}\text {-Video kaydı } \\
\text {-Görüşme formu ve ses kayıt- } \\
\text { ları } \\
\text {-Yansıtıcı günlükler } \\
\text {-Akran geribildirim formları } \\
\text {-Uygulama ortası algı anketleri }\end{array}$ \\
\hline $\begin{array}{l}\text { 9.hafta } \\
\text { (7. günlük } \\
\text { haftası) }\end{array}$ & $\begin{array}{l}\text { Öğretimi so- } \\
\text { mutlaştırıcı } \\
\text { yöntem ve } \\
\text { tekniklerden } \\
\text { yararlanma }\end{array}$ & $\begin{array}{l}\text {-Öğretim uygulaması } \\
\text { yapma ve yansıtma }\end{array}$ & $\begin{array}{l}\text { - Öğretim uygulamasını kayıt(video) altına } \\
\text { alma } \\
\text {-Yansıtıcı görüşme yapma } \\
\text {-Günlük geribildirimleri ve yeniden teslim } \\
\text { etme } \\
\text {-Akran önerileri yazma }\end{array}$ & $\begin{array}{l}\text {-Video kaydı } \\
\text {-Görüşme formu ve ses kayıt- } \\
\text { ları } \\
\text {-Yansıtıcı günlükler } \\
\text {-Akran geribildirim formları }\end{array}$ \\
\hline $\begin{array}{l}\text { 10.hafta } \\
\text { (8. günlük } \\
\text { haftası) }\end{array}$ & $\begin{array}{l}\text { Kavram ve } \\
\text { ilkeleri açık- } \\
\text { lama }\end{array}$ & $\begin{array}{l}\text {-Öğretim uygulaması } \\
\text { yapma ve yansıtma }\end{array}$ & $\begin{array}{l}\text { - Öğretim uygulamasını kayıt(video) altına } \\
\text { alma } \\
\text {-Yansıtıcı görüşme yapma } \\
\text {-Günlük geribildirimleri ve yeniden teslim etme } \\
\text {-Akran önerileri yazma }\end{array}$ & $\begin{array}{l}\text {-Video kaydı } \\
\text {-Görüşme formu ve ses kayıt- } \\
\text { ları } \\
\text {-Yansıtıcı günlükler } \\
\text {-Akran geribildirim formları }\end{array}$ \\
\hline $\begin{array}{l}\text { 11.hafta } \\
\text { (9. günlük } \\
\text { haftası) }\end{array}$ & $\begin{array}{l}\text { Dersin yöne- } \\
\text { timi ve sınıf } \\
\text { kontrolü }\end{array}$ & $\begin{array}{l}\text {-Öğretim uygulaması } \\
\text { yapma ve yansıtma }\end{array}$ & $\begin{array}{l}\text { - Öğretim uygulamasını kayıt(video) altına } \\
\text { alma } \\
\text {-Yansıtıcı görüşme yapma } \\
\text {-Günlük geribildirimleri ve yeniden teslim } \\
\text { etme } \\
\text {-Akran önerileri yazma }\end{array}$ & $\begin{array}{l}\text {-Video kaydı } \\
\text {-Görüşme formu ve ses kayıt- } \\
\text { ları } \\
\text {-Yansıtıcı günlükler } \\
\text {-Akran geribildirim formları }\end{array}$ \\
\hline $\begin{array}{l}\text { 12.hafta } \\
\text { (10.gün- } \\
\text { lük hafta- } \\
\text { sı) }\end{array}$ & $\begin{array}{l}\text { Öğretimde } \\
\text { sorulardan } \\
\text { yararlanma }\end{array}$ & $\begin{array}{l}\text {-Öğretim uygulaması } \\
\text { yapma ve yansıtma }\end{array}$ & $\begin{array}{l}\text { - Öğretim uygulamasını kayıt(video) altına } \\
\text { alma } \\
\text {-Yansıtıcı görüşme yapma } \\
\text {-Günlük geribildirimleri ve yeniden teslim } \\
\text { etme } \\
\text {-Akran önerileri yazma } \\
\text {-Uygulama sonu algı anketlerini uygulama }\end{array}$ & $\begin{array}{l}\text {-Video kaydı } \\
\text {-Görüşme formu ve ses kayıt- } \\
\text { ları } \\
\text {-Yansıtıcı günlükler (aynı hafta } \\
\text { içinde teslim edildi) } \\
\text {-Akran geribildirim formları } \\
\text {-Uygulama sonu algı anketle- } \\
\text { ri(aynı hafta içinde teslim edildi) }\end{array}$ \\
\hline
\end{tabular}




\section{Ek 2. Öğretmen adayının haftalık yansıtıcı düşünme günlüğü}

Ad Soyad:

Tarih: Hafta:

Uygulama sınıfi:

Ders:

Konu:

Kazanımlar:

\section{A. Dersin Hedefleri}

1.Öğrencilerin genel olarak dersi anlayıp anlamadıklarına ilişkin düşüncelerim:. verdiğime ilişkin düşüncelerim:.

2.Dersin ana hedeflerine ulaşılıp ulaşılamadığına ilişkin düşüncelerim:

Bunu nasıl ölçtüğüme ya da buna nasıl karar

.Ders sürecinde çok hizl ya da çok yavaş, çok zor ya da çok kolay

Bunu belirlemek için yaptıklarım:.

3.Ders sürecinde çok hızlı ya da çok yavaş, çok zor ya da çok kolay olan şeyler ve bunların nedenlerine ilişkin düşüncelerim:.

4.Bir sonraki ders hazırlığım için yapacağım yeni veya farklı şeyler : Nedenleri:.

5.Gelecek dersin kazanımları / hedefleri için planladıklarım:

\section{B. Etkinlikler ve Materyaller}

1.Kullandığım etkinlik ve materyal türleri: Bu etkinlikleri ve materyalleri nasıl seçtiğim ve seçme nedenlerim:

2.Etkinlik ve materyallerin etkili olup olmadığına ilişkin düşüncelerim: Nedenleri:

3.Dersin süresi ......dakikaydı/saatti. Ben dersin yaklaşık yüzde ....... kısmında aktiftim.Derste ben daha aktiftim. Çünkü:. Derste öğrenciler daha aktifti. Çünkü:.....

4.Etkinliklerin / materyallerin öğrencilerin ilgisini çekip çekmediğine ilişkin düşüncelerim: Nedenleri:

5.Öğrencilerin öğretim sürecinde en çok hoşlandıkları ve hiç hoşlanmadıkları şeyler:. Nedenleri:

6.Bu haftaki derste karşılaştı̆ım herhangi "sürpriz" olay(lar): Bu sürprizlerin dersi nasıl etkilediğine ilişkin düşüncelerim:.....

7.Derste yeterince farklı etkinlik ve materyal kullanıp kullanmadığıma ilişkin düşüncelerim:. Nedenleri:

8.Kullanabileceğim daha farklı etkinlik ve materyallere ilişkin düşüncelerim :

9.Dersin devamı olarak gelecek dersin planlaması hakkındaki düşüncelerim:.

\section{Sınıf Yönetimi}

1.Öğrencilerin ilgisinin konu üzerinde olup olmadığına(derste yapıyor olmaları gereken şeyleri yapıp yapmadıklarına) ilişkin düşüncelerim: ....Nedenleri:...

2.Sınıf içi kuralların ve yönergelerin açık olup olmadığına ilişkin düşüncelerim:...

3. Sınıf içinde karşılaştığım herhangi bir sorunlu öğrenci davranışı :... Yaşadığım bu sorunlu davranış(lar)ın neden(ler)i:....Bu sorunlu davranış(lar)ı nasıl çözdüğüm:....

4.Öğrencilerin bireysel olarak akademik ve davranışsal ihtiyaçlarını karşılayıp karşılayamadığıma ilişkin düşüncelerim:......Nasıl karşıladığım /Neden karşılayamadı̆̆ım:...

5.Etkinlikler arasındaki geçişlerin esnek olup olmadığına ilişkin düşüncelerim:....Örneğin:....

6.Tüm öğrencilerin derse katılmaları için firsatlar verip vermediğime ilişkin düşüncelerim:

7.Bir sonraki dersim için sınıf yönetimi açısından yapmak istediğim değişiklikler:....Nedenleri:....

\section{Genel olarak}

1.Dersi tekrar yapma şansım olsaydı, aynı yapmak istediğim şeyler: Farklı yapmak istediğim şeyler:

2.Yukarıdaki soruları ve cevaplarını incelediğimde, ihtiyaç duyduğum kaynaklar ve bilgiler: Kendimi yetersiz hissettiğim yerler ve yetersiz hissetme nedenlerim:......

3.Yaşadığım ders deneyimini ifade edebileceğim tek bir sözcük/sıfat:... 


\section{Ek 3. Öğretmenlik uygulaması dersi yansıtıcı görüşme formu}

1. İşlemiş olduğunuz dersi genel olarak nasıl değerlendirirsiniz?

a. Dersin genelini düşündüğünüzde dersin güçlü bulduğunuz yönleri nelerdi?

b. Dersin genelini düşündüğünüzde dersin zayıf bulduğunuz yönleri nelerdi?

c. Dersin genelini düşündüğünüzde yaşadığınız olumlu /olumsuz durumlar oldu mu?

d. Yaşadığınız olumlu /olumsuz durumlar nelerdi? Nedenleri neydi? Açıklar mısınız?

e. Yaşadığınız deneyimi tek bir sözcükle nasıl tanımlarsınız?

2. Dersin hedeflerini / kazanımlarını siz mi hazırladınız? /kim hazırladı?

a. Siz hazırladıysanız neleri dikkate alarak hazırladığınızı belirtir misiniz?

b. Siz hazırlamadıysanız, hedeflerin/ kazanımların öğrencilerin gelişim, yaş ve öğrenme düzeyleri açısından hangi oranda uygun olduğunu düşünüyorsunuz?

c. Yeniden hazırlama imkanınız olsaydı neleri değiştirirdiniz?

3. Dersin hedeflerine ulaştiğınızı düşünüyor musunuz? ( Neden?)

a. Dersin başarılı olduğunu düşünüyor musunuz? Neden?

b. Bu duruma nasıl karar verdiniz?

c. Sizce neler olsaydı hedeflere daha iyi ulaşılabilirdi?

4. Planlanan öğrenme çıktılarına ulaşmak için ne tür koşulların sağlanmasını önemli buluyorsunuz?

a. Ders sırasında, hangi ödevler/ faaliyetler / etkinlikler sonuçlar üzerinde etkiliydi?

b. Dersin sonundaki öğrenme ürünlerini (bilgi, beceri, tutum vb. ) düşününüz. Bu öğrenme ürünleri üzerinde etkisi olan koşullar nelerdir?

i. Öğretmen öğretim teknikleri

ii. Sınıf yönetimi

iii. Dönüt

iv. Hataları düzeltme

v. Sorgulama teknikleri

5. Dersiniz sürecinde hangi öğretim strateji, yöntem ve tekniğini veya tekniklerini kullandınız? Bunları seçmenizin nedeni nedir?

6. Ders sırasında beklenmedik / planlanmayan olaylar / sorunlar yaşandı mı?

a. Ders sırasında ders planınızda göz önünde bulunduramadığınız beklenmedik sorunlar / olaylar olduğunu düşünüyor musunuz? Evet, ise, bunlar nelerdir?

b. Onların üstesinden geldiğinizi düşünüyor musunuz? Evet ise nasıl? Hayır ise sizce neden?

7. Öğrencilerin dersiniz sırasındaki davranışları hakkında neler düşünüyorsunuz?

8. İşlenen dersteki öğrenme sürecini daha iyi bir duruma getirmek için alternatif bir pedagojik yaklaşımdan bahsedebilir misiniz?

a. İşlediğiniz ders için planlayabileceğiniz daha farklı bir öğretme süreci düşünebiliyor musunuz? Açıklar mısınız?

b. Bu dersi farklı bir yaklaşımla öğretseydiniz, öğrencilerin öğrenmesi kolaylaşır mıydı? Eğer evet ise, hangi yaklaşım (lar) ve nasıl?

c. Farklı öğretme yöntemleri kullansaydınız, öğrenciler daha iyi öğrenirler miydi? Eğer evet ise, dersin bu yöntemlerle nasıl öğretilmesi gerektiğini düşünüyorsunuz?

9. Dersin sonunda planlanmayan ya da istenmeyen öğrenmeler / öğrenme ürünleri gerçekleşti mi?

a. Dersin sonunda planlanmayan, istenmeyen öğrenmeler / öğrenme ürünleri olduğunu düşünüyor musunuz? Eğer olduğunu düşünüyorsanız, bunlar nelerdir? Nedenleri ile birlikte açıklar mısınız?

b. Dersin sonunda eksik kalan öğrenmeler / öğrenme ürünleri olduğunu düşünüyor musunuz? Eğer olduğunu düşünüyorsanız, bunlar nelerdir? Nedenleri ile birlikte açıklar mısınız?

10. Bu dersin konusunun öğrenciler için önemli/gerekli olduğunu düşünüyor musunuz?

a. Dersin önemli/gerekli olduğunu bir ebeveyne, yöneticiye ve / veya öğrenciye nasıl açıklarsınız?

b. Eğer bu dersin önemini /gerekliliğini bir ebeveyne, yöneticiye ve / veya öğrenciye açıklamak zorunda olsaydınız, onları nasıl ikna ederdiniz?

11. Dersiniz ile ilgili değiştirmek istediğiniz bir şey(ler) var mı? Tekrar bu sınıfa derse girecek olsanız yaşadığınız öğretmenlik deneyimine ilişkin neleri değiştirirdiniz? Neden? 


\section{Ek 4. Öğretmen adaylarının haftalık akran önerileri}

Adınız Soyadınız:

Dersini Gözlemlediğiniz Öğretmen Adayının;

Adı Soyadı: .................. Tarih/Hafta:

Uygulama sınıfi: ............ Dersi:

Konusu:

Arkadaşınızın dersinin etkiliğini göz önünde bulundurarak ona neler yapmasını önerirsiniz? Neden?

a. Dersin işlenişine yönelik önerilerim; (giriş, öğrenme-öğretme süreci ve ölçme değerlendirme)...........

b. Öğrenme-öğretme sürecine (strateji , yöntem, teknik, etkinlik ve materyallerin öğrencilerin öğrenme stillerine/ilgilerine/ihtiyaçlarına uygunluğu vb.) yönelik önerilerim;.....

c. Sınıf yönetimi (sorun çözme, iletişim, öğrenci-öğretmen rolleri, zamanı verimli kullanma vb.) ile ilgili önerilerim;

d. ve benzeri önerilerim;.

\section{Ek 5. Uygulama ortası algı ve değerlendirme anketi}

1. Uygulama okullarındaki uygulamalarınız sonrasında haftalık olarak yapılan görüşmelerin öğretmenlik becerilerinizin gelişimine ( ders planı, öğretme süreci vb.) hangi oranda katkı sağladığını düşünüyorsunuz? Nedenleri ile birlikte açıklayınız

2. Uygulama okullarındaki uygulamalarınıza ilişkin haftalık tutulan video kayıtlarının öğretmenlik becerilerinizin gelişimine( ders planı, öğretme süreci vb.) hangi oranda katkı sağladığını düşünüyorsunuz? Nedenleri ile birlikte açıklayınız.

3. Öğretmen adaylarıyla işbirliği içerisinde birbirinizin derslerine (uygulamalarınıza) ilişkin verdiğiniz akran dönütlerinin (önerilerinin) öğretmenlik becerilerinizin gelişimine ( ders planı, öğretme süreci vb.) hangi oranda katkı sağladığını düşünüyorsunuz? Nedenleri ile birlikte açıklayınız..

4. Haftalık olarak tuttuğunuz yansıtıcı düşünme günlüğünüzün öğretmenlik becerilerinizin gelişimine ( ders planı, öğretme süreci vb.) hangi oranda katkı sağladığını düşünüyorsunuz? Nedenleri ile birlikte açıklayınız .

5. Uygulama sürecinde kendi rolünü nasıl görüyorsun/değerlendiriyorsun? Lütfen nedenini açıklayınız.

6. Uygulama sürecinde üniversitedeki öğretim üyesinin rolünü nasıl görüyorsun/değerlendiriyorsun? Lütfen nedenini açıklayınız.

7. Uygulama sürecinde uygulama yaptığın okuldaki rehber öğretmeninin rolünü nasıl görüyorsun/değerlendiriyorsun? Lütfen nedenini açıklayınız.

8. Uygulama sürecine ilişkin diğer görüş ve önerileriniz.

\section{Ek 6. Uygulama sonu algı ve değerlendirme anketi}

1. Uygulama süresi boyunca her hafta öğretme süreçleriniz (karşılaştığınız problemler, planlanmayan durumlar vb.) üzerinde düşündünüz/konuştunuz/tartş̧tınız. Bu konuda neler hissediyorsunuz? Bunun öğretmenlik becerilerinizin gelişimine (ders planı, öğretme süreci vb.) hangi oranda katkı sağladıı̆ını düşünüyorsunuz? Lütfen nedenleri ile birlikte açıklayınız.

2. Uygulama süresi boyunca haftalık olarak yapılan görüşmeler konusunda neler hissediyorsunuz? öğretmenlik becerilerinizin gelişimine ( ders planı, öğretme süreci vb.) hangi oranda katkı sağladığını düşünüyorsunuz? Nedenleri ile birlikte açıklayınız

3. Uygulama süreci boyunca dersinize ilişkin tutulan haftalık video kayıtları konusunda neler hissediyorsunuz? Bu kayıtların öğretmenlik becerilerinizin gelişimine ( ders planı, öğretme süreci vb.) hangi oranda katkı sağladığını düşünüyorsunuz? Nedenleri ile birlikte açıklayınız

4. Uygulama süresi boyunca öğretmen adaylarıyla işbirliği içerisinde birbirinizin derslerine ilişkin verdiğiniz akran dönütleri (önerileri) konusunda neler hissediyorsunuz? Bu dönütlerin öğretmenlik becerilerinizin gelişimine ( ders planı, öğretme süreci vb.) hangi oranda katkı sağladığını düşünüyorsunuz? Nedenleri ile birlikte açıklayınız

5. Uygulama süresi boyunca haftalık olarak tuttuğunuz yansıtıcı düşünme günlükleriniz hakkında neler hissediyorsunuz? Bu günlüklerin öğretmenlik becerilerinizin gelişimine ( ders planı, öğretme süreci vb.) hangi oranda katkı sağladığını düşünüyorsunuz? Nedenleri ile birlikte açıklayınız

6. Uygulama süresi boyunca ders planları hazırlamanız konusunda neler hissediyorsunuz? Bu planların öğretmenlik becerilerinizin gelişimine ( ders planı, öğretme süreci vb.) hangi oranda katkı sağladığını düşünüyorsunuz? Nedenleri ile birlikte açıklayınız

7. Uygulama sürecinin başlangıcındaki beklentileriniz nelerdi? Uygulama süreci sonunda beklentilerinizin karşılandığını düşünüyor musunuz? Lütfen açıklayınız.

8. Uygulama sürecini düşündüğünüzde bu sürecin geliştirilmesine yönelik önerileriniz nelerdir?

9. Uygulama sürecinin başı ve sonunu göz önünde bulundurarak diğer hissettikleriniz/ düşünceleriniz nelerdir?oranda katkı sağladığını düşünüyorsunuz? Nedenleri ile birlikte açıklayınız. 